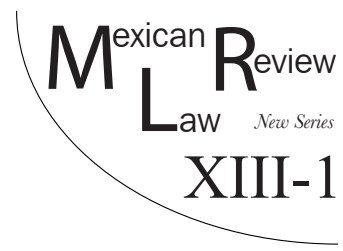

\title{
HOW DARE YOU! A GOMPARATIVE ANALYSIS OF GONSTITUTIONAL COURT DEGISIONS REGARDING INSULT LAWS IN MEXICO AND SOUTH KOREA
}

\author{
Yoomin WoN*
}

\begin{abstract}
Expressions that criticize the head of state, governmental institutions, or public officials are frequently sanctioned by criminal punishment for their use of derogatory and disrespectful language, referred to in the law as "insults". This article analyzes four judicial review decisions from the Supreme Court of Mexico and the Constitutional Court of Korea regarding insult laws from the perspective of both international human rights law and constitutional law. I argue that criminally punishing insulting expressions directed against public officials, symbols, or entities, violates the principle of freedom of expression. First, the "dignity of the nation" is not a legitimate interest warranting the restriction of insulting expressions directed at national flags or the Republic. Second, public officials should be required to tolerate a greater degree of insult than private individuals. Protection of a public function, or the honor of a public official, does not justify criminal punishment of insulting expressions. Third, the term "insult" itself is too vague, thus, its use breaches the principle of legality clarity. It also substantively restricts freedom of expression by prohibiting a wide range of utterances and activities. Based on this analysis, I argue that criminal punishment for expressions directed against national flags, public officials, and the nation, should be removed from the criminal codes. Neither the courts nor governmental authorities should criminally punish insulting expressions directed against public officials. Eliminating insult laws would not harm, but rather strengthen, democratic society in both Mexico and South Korea.
\end{abstract}

* Assistant Professor, Seoul National University School of Law,yoomin@snu.ac.kr.

This article was funded by the 2020 Research Fund of the Seoul National University AsiaPacific Law Institute, donated by the Seoul National University Law Foundation.

I would like to express my special gratitude to all the Mexican lawyers who helped me understand the Mexican legal system. This article resulted from my internship in the summer of 2016 at the Mexican Supreme Court. I thank Ministro José Ramón Cossío Díaz and the lawyers on his team for their warm welcome and hospitality. I also thank my dear friends Diana Esther Guzmán, Rolando Garcia Miron, and Franz Erwin Oberarzbacher Dávila who encouraged me and kindly helped me with this article. 
Esta revista forma parte del acervo de la Biblioteca Jurídica Virtual del Instituto de Investigaciones Jurídicas de la UNAM

Keywords: Insult law, Supreme Court of Mexico, Constitutional Court of Korea, international human rights law.

RESUMEN: Las expresiones que critican al jefe de Estado, instituciones gubernamentales of funcionarios públicos suelen estar restringidas por normas penales que castigan los insultos y ultrajes en contra de quienes representan al Estado. Este artículo analiza cuatro sentencias judiciales de la Suprema Corte de Justicia de la Nación (México) y la Corte Constitucional de Corea sobre las denominadas leyes contra insultos ("insult laws") tanto desde la perspectiva del derecho internacional de los derechos humanos como del derecho constitucional. Sostengo que castigar penalmente los insultos contra funcionarios, simbolos o entidades públicos viola la libertad de expresión. Primero, la dignidad de la nación no es un interés legítimo para restringir las expresiones ofensivas contra las banderas nacionales o la República. Segundo, los funcionarios públicos deben tener mayor tolerancia a la crítica que los particulares. La protección de la función pública o el honor de un funcionario público no justifica el castigo penal de las expresiones verbales de insulto. Tercero, el término "insulto (ultraje)" es demasiado vago y por lo tanto viola el principio de legalidad (claridad). También viola sustancialmente la libertad de expresión al restringir una amplia gama de expresiones. Con base en este análisis, defiendo que los tipos penales que castigan las expresiones contra símbolos patrios, funcionarios públicos y la nación deben eliminarse de los códigos penales, y los funcionarios encargados de aplicarlos deben dejar de imponer castigos con base en ellos. Eliminar las leyes contra insultos fortalecería el debate democrático tanto en México como en Corea del Sur.

Palabras Clave: Insulto, Suprema Corte de Justicia de la Nación (México), Corte Constitucional de Corea, derecho internacional de derechos humanos.

\section{TABle of Contents}

I. INTRODUCTION.

II. International Human Rights Law Regarding Insult Laws ...... 105

1. Universal System............................................................. 105

2. Inter-American System ................................................. 108

III. Constitutional Protection for Freedom of Expression ......... 110

1. Political Constitution of the United Mexican States ............... 110

2. Constitution of the Republic of Korea................................ 113

IV. Decisions of the Supreme Court of Mexico Regarding

INSULT LaWs

1. Insult to the National Flag Case in 2005 (Amparo en Revisión 2676/2003, case no. 1)

2. The Insult to Authority Case in 2016 (Amparo Directo en Revisión 2255/2015, case no. 2) 
V. Decisions of the Gonstitutional Gourt of Korea on Insult LaWs

1. Insult as a Criminal Offense Case in 2013 (2012Hun-Ba37, case no. 3)

2. Insult to the Republic of Korea Case in 2015 (2013Hun-Ka20, case no. 4)

VI. Comparative Analysis of the Decisions

1. Is Protecting the Dignity of the Nation a Legitimate Purpose of Insult Laws?

2. Insult to Public Officials: More Tolerant or More Strict?.

3. Constitutional Standards: "Insult", Too Vague or Too Broad?

VII. Conclusions and Suggestions.

\section{INTRODUCTION}

The American singer, Miley Cyrus, enraged many Mexicans when a Mexican flag was used to spank false buttocks she was wearing during her concert in Monterrey, Mexico on Mexico's Independence Day, September 16, 2014. What was more problematic than the public outrage is that insulting the national flag in Mexico is illegal, and punishable by a fine of up to approximately $\$ 1,200$ and three days of jail in the state of Nuevo León where the concert took place. ${ }^{1}$ It is a criminal offense to use a Mexican flag in a disrespectful way - physically or verbally. A poet who once merely described himself using a Mexican flag as toilet paper in a poem was criminally punished. In that case, the Supreme Court of Mexico upheld the criminal punishment of the poet, declaring it to be constitutional despite the poet's argument that his freedom of expression had been violated. ${ }^{2}$

Freedom of expression is protected as a fundamental right in the constitutions of most democratic countries, ${ }^{3}$ as well as in international human rights documents. However, such freedom of expression is often restricted in order to achieve certain specifically defined purposes, such as protecting the honor or privacy of another person, or preserving public order. The varying scope of these restrictions often leads to the uncomfortable question as to whether opinions shared only by a minority of people are more legally constrained than other more popular opinions. In particular, expressions that criticize

1 Rafael Romo, Miley Cyrus' Mexican flag stunt drawes official condemnation, investigation, CNN (Sep. 22, 2014), https://werere.cnn.com/2014/09/18/showbiz/miley-cyrus-mexican-flag/index.html.

2 Primera Sala de la Suprema Corte de Justicia de la Nación [SCJN], Amparo en Revisión, $2676 / 2003$.

3 Elena Yanchukova, Criminal Defamation and Insult Laws: An Infringement on the Freedom of Expression in European and Post-Communist furisdictions, 41 Colum. J. TransnaT'L L. 861, 861 (2002). 
the head of state, governmental institutions, or public officials, are frequently subject to criminal punishment for their use of derogatory and disrespectful language, referred to in the law as "insults". 4

The constitutionality of insult laws is addressed in national constitutional courts. Four decisions of the Supreme Court of Mexico (La Suprema Corte de Fusticia de la Nación, hereinafter, "Mexican Court") and the Constitutional Court of Korea (hereinafter, "Korean Court") have considered various aspects of several different insult laws. In the first Mexican decision to be examined here, a law prohibiting insults directed at the national flag was declared constitutional by the First Chamber of the Supreme Court of Mexico in 2005. ${ }^{5}$ In the second Mexican decision, from 2016, the court declared unconstitutional a criminal provision prohibiting "insult to authority (ultraje a la autoridad)". ${ }^{6}$ The first decision from the South Korean court evaluated an insult law as a general criminal offense and determined it to be constitutional in $2013 .^{7}$ The second Korean decision, from 2015, held that a criminal provision against insults to the Republic violates freedom of expression. ${ }^{8}$ The Korean decisions were selected for their common component of "insult" warranting criminal punishment, which allows for a comparative analysis, and also highlights its importance in the Korean constitutional law jurisprudence.

These four decisions, when analyzed together, raise several questions about expressions that are alleged to be disrespectful to the authority or dignity of the state and its public officials. Is the dignity of the nation a sufficiently legitimate interest to justify restricting these expressions? Are there other legitimate interests sufficient to justify restrictions of such expressions against public entities, such as protecting the exercise of a public function or the honor of a public official? Is the term "insult" itself too vague or too broad to be criminalized? These decisions also raise the question as to which constitutional standard is appropriately applied in these cases, the principle of legality, or the substantive review of freedom of expression. In this article I will analyze these four decisions, bearing in mind the above questions.

4 Badala Tachilisa Balule, Insult laws: a challenge to media freedom in the SADC's fledgling democracies?, 41 Comparative and International Law Journal of Southern Africa 403, 405-406 (2009). Insult laws and criminal defamation in many countries excessively restricts the freedom of expression. See Patti MaCracken, Insult Laws Insulting to Press Freedom. A Guide to Evolution of Insult Laws in 2010 (World Press Freedom Committee and Freedom House. 2012). Clooney and Webb analyze state practice on insult laws using categories of insulting rulers, insulting religion and insulting royalty. Amal Clooney \& Philippa Webb, The Right to Insult in International Law, 48 Colum. Hum. RTs. L. Rev. 1, 3-14 (2016).

5 Primera Sala de la Suprema Corte de Justicia de la Nación [SCJN], supra note 2.

6 Pleno de la Suprema Corte de Justicia de la Nación [SGJN], Amparo Directo en Revisión, 2255/2015.

7 Constitutional Court [Const. Ct.], 2012Hun-Ba37, Jun. 27, 2013 (2013 D.K.C.C. 1).

8 Constitutional Court [Const. Ct.], 2013Hun-Ka20, Oct. 21, 2015 (2015 D.K.C.C. 160). 
This article will examine specific issues related to freedom of expression with the following three limitations. First, regarding the content of an expression, the focus will be on freedom of expression directed against a public entity, which includes individual public officials, governmental institutions as well as symbols of the nation. This will exclude expressions that might harm the honor or privacy of a private person or expressions made by the media. (While the third decision in this article is about an insult law that punished an insulting expression against a private person, I will explain how it was misused, in fact, to prohibit insults directed toward public officials.) This will also exclude "hate speech" designed to promote hatred on the basis of race, religion, ethnicity, national origin, etcetera. ${ }^{9}$ Second, I will restrict the analysis to insult laws that impose criminal punishment. Accordingly, insult laws that allow for civil liability will not be studied in this article. Third, I will focus only on laws that regulate "insulting" expressions. For example, the mere circulation of false facts or defamation will not be examined. This paper will examine insult laws that explicitly criminalize "insult" ("ultraje" in Spanish, "모욕" in Korean) as a criminal offense. ${ }^{10}$

In this article, I will first analyze how international human rights law responds to national insult laws (Part I). I will then discuss the constitutional protection of freedom of expression in Mexico and South Korea (Part II). Next, I will examine the Mexican Court decisions in the cases regarding insult to the national flag and insult to authority (Part III). The following section will cover insult as a criminal offense and insult to the Republic, the two Korean Court cases under examination here (Part IV). In the last section, I will analyze and compare three key aspects of the insult law cases from these two countries: the dignity of the nation as a legimate governmental interest, insult to public officials, and the constitutional standards applied in the cases (Part V). Finally, I will conclude by outlining the reasons insult laws should be abolished, or in the alternative, subject to a more strict interpretation by the judiciary. My analysis focuses on Mexico and South Korea as representative of common legal practices on insult laws in many different countries. ${ }^{11}$

\section{International Human Rights Law Regarding Insult Laws}

\section{Universal System}

Freedom of expression is protected not only by domestic constitutions but also in international human rights documents. The Universal Declaration of

9 Michel Rosenfeld, Hate Speech in Constitutional Furisprudence: A Comparative Analysis, 24 CARDOzo L. Rev. 1523, 1523 (2002).

10 Clooney and Webb enumerate seven factors regarding context of an insult. Clooney \& Webb, supra note 4, at 24-37.

11 South Korea ranked no. 41 and Mexico ranked no. 144 out of 180 countries in the World Press Freedom Index 2019. Reporters Without Borders, 2019 World Press Freedom Index, available at https://rsforg/en/ranking?\#. 
Human Rights, adopted in 1948, protects freedom of opinion and expression in Article 19. "Article 19 Everyone has the right to freedom of opinion and expression; this right includes freedom to hold opinions without interference and to seek, receive and impart information and ideas through any media and regardless of frontiers".

Freedom of expression is also protected by the International Covenant on Civil and Political Rights, adopted in 1966, which both Mexico and South Korea ratified in 1975 and 1990, respectively. ${ }^{12}$

Article 19

1. Everyone shall have the right to hold opinions without interference.

2. Everyone shall have the right to freedom of expression; this right shall include freedom to seek, receive and impart information and ideas of all kinds, regardless of frontiers, either orally, in writing or in print, in the form of art, or through any other media of his choice.

3. The exercise of the rights provided for in paragraph 2 of this article carries with it special duties and responsibilities. It may therefore be subject to certain restrictions, but these shall only be such as are provided by law and are necessary:

(a) For respect of the rights or reputations of others;

(b) For the protection of national security or of public order (ordre public), or of public health or morals. ${ }^{13}$

The Human Rights Committee, a treaty-body that interprets the above Covenant and monitors its implementation, highlighted the importance of freedom of expression emphasizing that it "constitutes one of the cornerstones of a democratic society" and that "the free communication of information and ideas about public and political issues between citizens, candidates and elected representatives are essential."14 The Committee clarified its position regarding limitations on freedom of expression in its General Comment No. 34 in 2011 stating that criminalization of an opinion is not compatible with Article 19 paragraph 1 of the Covenant ${ }^{15}$ which prohibits the harassment, intimidation or stigmatization of a person, including arrest, detention, trial or imprisonment for holding opinions. ${ }^{16}$

Moreover, the Human Rights Committee provides guidelines addressing laws designed to prohibit and punish expressions that insult public figures, ${ }^{17}$

12 For the draft history of Article $19 \& 20$ of the ICCPR and Article 4 of the International Convention on the Elimination of All Forms of Racial Discrimination, see Clooney \& Webb, supra note 4 , at 15-21.

13 Clooney and Webb posit that the terms of restrictions, such as "respect for the right of others" "protection of morals" are too vague. Clooney \& Webb, supra note 4, at 44.

14 Human Rights Comm., General Comment No. 34, U.N. Doc. CGPR/C/GC/34 (Sept. 12, 2011 ), para. 13, 20.

15 Clooney \& Webb, supra note 4, at 25-26, 28.

16 Human Rights Comm., supra note 14, para. 9.

17 Balule, supra note 4, 413-414. 
which is the focus of this article. All public figures are subject to criticism and political opposition. The mere fact that an expression insults a public figure does not justify imposition of criminal penalties. In this regard, the Committee expressed its concern about laws of "lese majesty, desacato, disrespect for authority, disrespect for flags and symbols, defamation of the head of state, and the protection of the honor of public officials". ${ }^{18}$

The Special Rapporteur on the promotion and protection of the right to freedom of opinion and expression, appointed by the UN Human Rights Council, addresses those types of laws. Concerning the countries of interest to the present discussion, Frank La Rue, the Special Rapporteur at that time, undertook an official mission to the Republic of Korea from May 6 through May 17 of 2010. He also visited Mexico with the Special Rapporteur for Freedom of Expression of the Inter-American Commission on Human Rights, Catalina Botero, from August 9 through August 24 of 2010. In his report on the South Korea mission, he recommended abolishing the criminal offense provisions of both defamation and insult, declaring they are "inherently harsh and have a disproportionate chilling effect on the right to freedom of expression." ${ }^{19} \mathrm{He}$ stressed that "public officials and bodies should refrain from filing defamation suits, since a public office entails public scrutiny as part of checks and balances in a democratic society". ${ }^{20}$ With respect to insult laws in Mexico, he acknowledged that the Mexican federal government and other federal states had decriminalized the crimes of libel, defamation, and slander, ${ }^{21}$ although other criminal punishments on the exercise of freedom of expression still remained. ${ }^{22}$ This was also reaffirmed in the Joint Report of the United Nations Special Rapporteur on the promotion and protection of the right to freedom of opinion and expression, David Kaye,

18 Human Rights Comm., supra note 14, para. 38.

19 Human Rights Council, Report of the Special Rapporteur on the promotion and protection of the right to freedom of opinion and expression, Frank La Rue, UN Doc. A/ HRC/17/27/Add.2, (Mar. 21, 2011), para. 27-28.

20 Human Rights Council, supra note 19, para.89. Park posits that international human rights standards about insult laws could be considered as interpretative tool in Korean courts. Kyung Sin Park, Special Feature: Current Issues in Constitutional Law; Freedom of Expression under International Law and Its Implications for Korean legal reform, 13 The LaW REASEARCH Institutute of HongIK UnIV. 87, 90-94 (2012) (in Korean).

21 Human Rights Council, Report of the Special Rapporteur on the promotion and protection of the right to freedom of opinion and expression, Frank La Rue, UN Doc. A/ HRC/17/27/Add.3, (May 19, 2011), para. 49. Article 350 to Article 355 of the Federal Criminal Code (of Mexico), which criminalized defamation and libel, were abolished on 13 April 2007.

22 Human Rights Council, supra note 21, para. 81. See Alma de los Ángeles Ríos Ruiz, El derecho de libertad de expresión en México a la luz del derecho comparado, 5 Revista In Jure Anáhuac МАҮАв 84, 93-94 (2016). 
and the Special Rapporteur for Freedom of Expression of the IACHR, Edison Lanza, in their mission to Mexico in 2017.23

\section{Inter-American System}

I will now turn to the protection of freedom of expression as part of a regional human rights system, focusing only on the Inter-American System of Human Rights. Mexico has been a member state of the OAS (Organization of American States) since 1948, and the Inter-American Convention on Human Rights since 1981. As for Korea, there is no regional human rights system. Freedom of thought and expression is protected under Article 13 of the Inter-American Convention on Human Rights.

Article 13. Freedom of Thought and Expression

1. Everyone has the right to freedom of thought and expression. This right includes freedom to seek, receive, and impart information and ideas of all kinds, regardless of frontiers, either orally, in writing, in print, in the form of art, or through any other medium of one's choice.

2. The exercise of the right provided for in the foregoing paragraph shall not be subject to prior censorship but shall be subject to subsequent imposition of liability, which shall be expressly established by law to the extent necessary to ensure:

a. respect for the rights or reputations of others; or

b. the protection of national security, public order, or public health or morals.

3. The right of expression may not be restricted by indirect methods or means, such as the abuse of government or private controls over newsprint, radio broadcasting frequencies, or equipment used in the dissemination of information, or by any other means tending to impede the communication and circulation of ideas and opinions.

The Inter-American Court of Human Rights, in an advisory opinion, interpreted freedom of expression to be a cornerstone of democratic society and an indispensable element in the formation of public opinion. It added that it is "the means that enable the community, when exercising its options, to be sufficiently informed". 24

23 Joint Report of the Special Rapporteur for Freedom of Expression of IACHR, Edison Lanza, and the United Nations Special Rapporteur on the promotion and protection of the right to freedom of opinion and expression, David Kaye, on their mission to Mexico, (Jun. 2018), para. 17, http://werere.oas.org/en/iachr/expression/docs/2018_06_18_CIDH-UN_FINAL_M X_report_ENG.pdf.

24 Compulsory Membership in an Association Prescribed by Law for the Practice of Journalism (Arts. 13 and 29 American Convention on Human Rights), Advisory Opinion OG5/85, Inter-Am. Ct. H.R. (ser. A), N. 5, para. 70. (of Nov. 13, 1985). 
With respect to insult laws specifically, expressions against public officials were first studied by the Inter-American Commission on Human Rights in its Annual Report in 1994. ${ }^{25}$ The Inter-American Commission included a chapter entitled "Report on the Compatibility of Desacato Laws with the American Convention on Human Rights". In this report, desacato laws are defined as "a class of legislation that criminalizes expression which offends, insults, or threatens a public functionary in the performance of his or her official duties". After a thorough study of this issue, the Inter-American Commission concluded that desacato laws are incompatible with Article 13 of the American Convention on Human Rights. Specifically, it announced that desacato laws are not legitimate restrictions of freedom of expression, nor are they necessary to ensure public order in a democratic society. ${ }^{26}$

This standard was reflected in subsequent documents, such as the Declaration of Principles on Freedom of Expression adopted by the Inter-American Commission on Human Rights in 2000. ${ }^{27}$ The Special Rapporteur on Freedom of Expression continued reporting about desacato laws in 1998, 2000, 2002, and 2004.28 Furthermore, the OAS Special Rapporteur adopted joint declarations with the UN Special Rapporteur on Freedom of Opinion and Expression, as well as the OSCE Representative on Freedom of the Media in 2000, declaring that defamation laws should reflect the importance of open debate about public concerns. ${ }^{29}$ In 2002, they reiterated that criminal defamation is not a justifiable restriction on freedom of expression and that all criminal defamation laws should be abolished and replaced with appropriate civil defamation laws. ${ }^{30}$ In 2010, the Tenth Anniversary Joint Declaration was adopted by the above Special Rapporteurs who identified ten key

25 Balule, supra note 4, at 412-413.

26 Inter-Am. Comm'n H.R., Annual Report of the Inter-American Commission on Human Rights 1994, http://cidh.oas.org/annualrep/94eng/chap.5.htm.

In 1994, the Inter-American Press Association held a conference on freedom of press at Chapultepec Castle in Mexico City, producing the Declaration of Chapultepec signed by the Heads of State of 21 of the regions. The Principle 10 states that "no news medium nor journalist may be punished for publishing the truth or criticizing or denouncing the government". Annual Report of the Office of the Special Rapporteur for Freedom of Expression of 2000, OEA/Ser./L/V/II.111. Doc. 20 rev. (Apr. 16, 2001), at 54, http://wrwre.oas.org/en/iachr/expression/docs/reports/annual/2000.pdf?DocumentID=13.

27 Declaration of Principles on Freedom of Expression, Principle 10 and Principle 11, http://wrw.oas.org/en/iachr/expression/showarticle.asp? artID =26\&IID =1.

28 Annual Report of the Office of the Special Rapporteur for Freedom of Expression of 1998, 2000, 2002, and 2004.

29 International Mechanisms for Promoting Freedom of Expression Joint Declaration 2000, http://wwre.oas.org/en/iachr/expression/showarticle.asp? artID=142 \&IID=1.

30 International Mechanisms for Promoting Freedom of Expression Joint Declaration 2002, http://wwre.oas.org/en/iachr/expression/showarticle.asp?artID=87 \&IID=1. 
challenges to freedom of expression for the following decade, declaring that criminal defamation represents an ongoing threat to freedom of expression. ${ }^{31}$

The Inter-American Court of Human Rights has also ruled on criminal defamation law cases. ${ }^{32}$ Since 2004, that Court has held that the right to freedom of expression was violated in prosecutions for criminal defamation against public officials or candidates and for contempt of authority (desacato) in Costa Rica, Paraguay, Chile, Argentina, and Venezuela. ${ }^{33}$

\section{Constitutional Protection for Freedom of Expression}

\section{Political Constitution of the United Mexican States}

Before analyzing the specific court decisions, it is necessary to examine how freedom of expression is protected by the constitutions of the two countries. First, in Mexico, Articles 6 and 7 of the Political Constitution of the United Mexican States guarantee freedom of expression as follows: ${ }^{34}$

Article 6. Expression of ideas shall not be subject to judicial or administrative inquiry, except for those cases when such expression of ideas goes against the moral, privacy or the rights of third parties, causes perpetration of a felony, or

31 Tenth Anniversary Joint Declaration: Ten Key Challenges to Freedom of Expression in the Next Decade 2010, http://www.oas.org/en/iachr/expression/showarticle.asp? artID=784 \&IID=1.

Insult law cases are also discussed in Europe. The European Court of Human Rights decided in 2013 that the French President should not be over-protected from satirical insult. Eon v. France, App. No. 26118/10, Eur. Ct. H.R., (Mar. 14, 2013). Before the 2013 decision, the European Court of Human Rights also decided in 2002 that punishing the publishing director and journalist of a French newspaper, Le Monde, for defamation of the King of Morocco violated freedom of expression by France. Colombani (Le Monde) v. France, App. No. 51279/99, (Jun 25, 2002).

32 Richard N Winfield \& Kristin Mendoza, The Abolition Movement: Decriminalizing Defamation and Insult Laws, 25 Comm. Law. 7, 8-9 (2007).

33 Herrera Ulloa v. Costa Rica, 2004 Inter-Am. Ct. H.R. (ser. C) No. 107 (Jul. 2, 2004); Canese v. Paraguay, 2004 Inter-Am. Ct. H.R. (ser. G) No. 111 (Aug. 31, 2004); Palamara Iribarne v. Chile, 2005 Inter-Am. Ct. H.R. (ser. G) No. 135, (Nov. 22, 2005); Kimel v. Argentina, 2008 Inter-Am. Ct. HR (Ser. G) No. 177 (May 2, 2008); Tristán Donoso Vs. Panamá, 2009 Inter-Am. Ct. HR (Ser. C) No. 193; Usón-Ramírez v. Venezuela, 2009 Inter-Am. Ct. HR (Ser. C) No. 207. Winfield and Mendoza also introduce recent decisions from the European Court of Human Rights on this issue. Winfield \& Mendoza, supra note 33, at 7-8.

The Declaration of Principles on Freedom of Expression in Africa recognizes that insult laws are subject to abuse. Balule, supra note 4, at 411.

34 For the meaning of the articles 6 and 7, see Francisca Pou Giménez, La libertad de expresión y sus limites, Derechos humanos en la Constitución. Jurisprudencia nacional e interamericana 901, 901-912 (2013). 
disturbs the public order. The right of reply shall be exercised according to law. The State shall guarantee the right to information. ${ }^{35}$

Article 7. Freedom of speech, opinion, ideas and information through any means shall not be abridged. Said right shall neither be abridged through any indirect means, such as abuse of official or private control over paper, radio electric frequencies or any other materials or devices used to deliver information, or through any other means or information and communication technologies aimed at impeding transmission or circulation of ideas and opinions.

No statute or authority shall establish prior restraints, nor shall it abridge freedom of speech, which shall be subject to no other limitation than those foreseen in the first paragraph of Article 6 of this Constitution. Under no circumstances shall the assets used for the transmission of information, opinions and ideas be subject to seizure on the grounds of being an instrumentality of a felony. ${ }^{36}$

The Supreme Court of Mexico has emphasized the importance of freedom of expression in a democracy as a means of communication. ${ }^{37}$ The Mexican Court stresses both the individual and public aspect of freedom of expression. On the one hand, the individual dimension of freedom of expression requires a high level of protection to ensure the fundamental value of individual autonomy. As a result, freedom of expression has been recognized as an indispensable condition for other forms of freedom. ${ }^{38}$ On the other hand, the political dimension of freedom of expression is a centerpiece of representative democracy. It emphasizes the importance of the free flow of ideas and opinions in debates on public issues. In this respect, freedom of expression is linked to political pluralism and the fundamental values of democratic states. ${ }^{39}$ It allows for a truly representative government in which citizens participate effectively in decisions involving the public interest. ${ }^{40}$

35 Article 6 of the Mexican Constitution establishes state's obligation not to interfere with the exercise of the freedom of expression and the limits for the exercise of this freedom. Ríos Ruiz, supra note 22 , at 87.

36 Translation by María Fernanda Gómez Abán, available at https://archivos.juridicas.unam. $m x /$ www/legislacion/federal/leyes/consting.pdf.

37 See also Libertad de Expresión. Dimensiones de su Contenido, Pleno de la Suprema Corte de Justicia de la Nación [SCJN], Semanario Judicial de la Federación y su Gaceta, Novena Época, tomo XXV, Mayo de 2007, Tesis P./J. 25/2007, Página 1520; José Ramón Cossío Díaz et al., La Libertad de Expresión en las Sentencias de la Suprema Corte de Justicia (2014), at 9.

38 Libertad de Expresión. Dimensión Individual de Este Derecho Fundamental, Primera Sala de la Suprema Corte de Justicia de la Nación [SCJN], Gaceta del Semanario Judicial de la Federación, Décima Época, Libro 13 Tomo I, Diciembre de 2014, Tesis Aislada, la. CDXX/2014 (10a.), Página 233.

39 Juan Antonio Cruz Parcero, De poemas, banderas, delitos y malas decisiones. La sentencia de la Suprema Corte sobre el caso Witz, 56 Revista de la Facultad de Derecho de México 423, 432 (2006).

40 Libertad de Expresión. Dimensión Política de Este Derecho Fundamental, Primera 
Regarding expressions directed at public officials and public figures, the Mexican Court adopted "the dual protection system (sistema dual de protección)" from the 2008 Report of the Special Rapporteur for Freedom of Expression of the Inter-American Commission on Human Rights in its decision of Amparo Directo en Revisión 2044/2008. ${ }^{41}$ Expressions directed at public officials and public figures enjoy a higher degree of protection, and such persons should have a higher threshold of tolerance for criticism. ${ }^{42}$ As criticism is essential in a democratic system, the permissible limits are more broad when critics are referring to people who engage in public activities. ${ }^{43}$ The threshold for criminal or civil responsibility for expressions against public officials is higher than for expressions against private individuals. ${ }^{44}$

However, not all of these types of expressions are protected by the Mexican Constitution. The SJCN specifically announced that the Mexican Constitution does not recognize the right to insult. Although the Constitution does not prohibit expressions that are unusual, alternative, indecent, outrageous or contrary to majority beliefs, insults are not protected by the Constitution. As a result, the right to honor prevails in cases regarding the expression of insults. However, the Mexican Court has also held that the political or social

Sala de la Suprema Corte de Justicia de la Nación [SCJN], Gaceta del Semanario Judicial de la Federación, Décima Época, Libro 13 Tomo I, Diciembre de 2014, Tesis Aislada, la. CDXIX/2014 (10a.), Página 234.

41 Primera Sala de la Suprema Corte de Justicia de la Nación [SGJN], Amparo Directo en Revisión, 2044/2008.

42 Libertad de Expresión y Derecho a la Información. Concepto de interés público de LAS EXPRESIONES, INFORMACIONES, IDEAS Y OPINIONES SOBRE FUNCIONARIOS Y CANDIDATOS, Primera Sala de la Suprema Corte de Justicia de la Nación [SCJN], Gaceta del Semanario Judicial de la Federación, Décima Época, Libro 5 Tomo I, Abril de 2014, Tesis Aislada, 1a. CLII/2014 (10a.), Página 806; Cossío Díaz et al., supra note 38, at 11.

43 Libertad de Expresión y Derecho a la Información. Su protección es especialmente INTEnsa en materia POlÍtica y asuntos De Interés Público, Primera Sala de la Suprema Corte de Justicia de la Nación [SCJN], Semanario Judicial de la Federación y su Gaceta, Novena Época, Tomo XXX, Diciembre de 2009, Tesis Aislada, la. CCXVII/2009, Página 287.

44 Libertad de Expresión y Derecho a la Información. La RESPONSABILIDAD POR INVASIONES AL HONOR DE FUNCIONARIOS U OTRAS PERSONAS CON RESPONSABILIDADES PÚBLICAS SÓLO PUEDE DARSE Bajo CiERTAS CONDiCiONES, MÁs ESTRICTAS QUE LAS QUE SE APLICAN EN EL CASO DE EXPRESiOnes o informaciones referidas a ciudadanos Particulares, Primera Sala de la Suprema Corte de Justicia de la Nación [SGJN], Semanario Judicial de la Federación y su Gaceta, Novena Época, Tomo XXX, Diciembre de 2009, Tesis Aislada, la. CCXXI/2009, Página 283.

One of the main consequences of dual protection system is the "actual malice", which imposes civil penalties only in cases where false information (in case of the right to information) or has been produced with "actual malice" (applicable to both the right to information as to freedom of expression). LiberTad de Expresión. Sus límites a LA LuZ DEL SISTEMa de PROTECCión dual y del estándar de malicia efectiva, Primera Sala de la Suprema Corte de Justicia de la Nación [SCJN], Semanario Judicial de la Federación y su Gaceta, Décima Época, Libro XIX Tomo 1, Abril de 2013, Tesis Jurisprudencial, 1a./J. 38/2013 (10a.), Página 538. 
situation of a State, and circumstances of the expression itself, may mitigate the offense and permit an increased degree of tolerance. ${ }^{45}$

As noted above, the Mexican federal government and other federal states did decriminalize the crimes of libel, defamation, and slander, ${ }^{46}$ although other laws that allow criminal punishment for the exercise of freedom of expression still remain. ${ }^{47}$

\section{Constitution of the Republic of Korea}

The Constitution in South Korea protects freedom of expression in Article 21, which provides as follows:

Article 21

(1) All citizens shall enjoy freedom of speech and the press, and freedom of assembly and association.

(2) Licensing or censorship of speech and the press, and licensing of assembly and association shall not be permitted.

(3) The standards of news service and broadcast facilities and matters necessary to ensure the functions of newspapers shall be determined by Act.

(4) Neither speech nor the press shall violate the honor or rights of other persons nor undermine public morals or social ethics. Should speech or the press violate the honor or rights of other persons, claims may be made for the damage resulting therefrom. ${ }^{48}$

Article 21 protects both freedom of speech and freedom of the press, that is, freedom of expression. Since shortly after its inauguration in 1988, the Constitutional Court of Korea ("Korean Court") has emphasized the importance of freedom of expression, holding it to be one of the most important fundamental rights in a democratic nation and essential to individual human dignity and the pursuit of happiness. ${ }^{49}$ The Korean Court has also underscored the dual constitutional aspect of freedom of expression: it is necessary not only for individual self-fulfillment, but for democracy itself.

The Korean Court has held that in a free and democratic system, where ruler and ruled are one, the public needs to know about the decisions and actions of political leaders. Freedom of expression is not only a means of

45 Libertad de Expresión. La Constitución no reconoce el derecho al insulto. Primera Sala de la Suprema Corte de Justicia de la Nación [SCJN], Semanario Judicial de la Federación y su Gaceta, Décima Época, Libro XIX Tomo 1, Abril de 2013, Tesis Jurisprudencia, 1a./J. 31 /2013 (10a.), Página 537.

46 Human Rights Council, supra note 21, para. 49. McCracken, supra note 4, at 100-101.

47 Human Rights Council, supra note 21, para. 81. Ríos Ruiz, supra note 22, at 93.

48 Translation from the website of the Constitutional Court of Korea, wwrw.ccourt.go.kr.

49 Constitutional Court [Const. Ct.], 89Hun-Ka104, Feb. 25, 1992 (4 K.C.C.R. 64). 
promoting individual self-fulfillment and the pursuit of truth, it also allows individuals to participate in the development of political and social policy. Democratic societies do not subscribe to the belief in the infallibility of the government. The government, as well as individuals in governmental positions, may commit errors. Considering the historical evidence of errors committed by those in positions of power, a truly democratic system should promote the idea that government can minimize errors by subjecting itself to public criticism. Typically, freedom of expression has a superior constitutional claim to all other fundamental rights because it forms the basis on which a self-governing system functions, allowing the ruled to actively participate in the system by criticizing the those holding positions of political authority. ${ }^{50}$

The Korean Court applies a different standard when reviewing freedom of expression when it concerns public figures or the public interest. It has held that:

depending on the whether the victim of the defamatory statement is a public or a private figure and whether the statement is a matter of public concern or a matter in a purely private area, there should be a difference in the constitutional standard of review. Restrictions on defamatory statements against public figures concerning their public activities should be relatively more relaxed than those against private figures.

Even matters concerning a public official's personal life may fall within the scope of public concern in some cases. Nevertheless, the Korean Court does limit freedom of expression when it is directed against a public figure or involves a public concern. The Court has held that "An attack against an individual that is malicious or substantially lacks reasonableness, both based on a clearly false statement exceeding the acceptable level of exaggeration in the ordinary sense, may be subject to restriction". ${ }^{51}$

\section{Decisions of the Supreme Court of Mexico REGARDING INSULT LaWs}

The first Mexican decision under examination here was rendered by the First Chamber of the Mexican Court on October 5, 2005 (Amparo en Revisión 2676/2003). In that case, the Mexican Court upheld the constitutionality of Article 191 of the Federal Penal Code, which allows for imprisonment from six months to four years and/or a fine of 50 to 3,000 pesos for anyone who insults the coat of arms of the Republic or the national flag, either in word

50 Constitutional Court [Const. Ct.], 89Hun-Ka104, Feb. 25, 1992 (4 K.C.C.R. 64), at 94-95.

51 Constitutional Court [Const. Ct.], 2009Hun-Ma747, Dec. 26, 2013 (2013 D.K.C.C. 205), at 207-208. 
or action. The second Mexican decision to be examined here was reached by the Full Chamber of the Mexican Court on March 7, 2016 (Amparo Directo en Revisión 2255/2015). In that case, the Mexican Court declared Article 287 of the Penal Code for the Federal District to be unconstitutional in this particular case when applied to a crime committed against a public servant while in the performance of his or her lawful functions.

\section{Insult to the National Flag Case in 2005 (Amparo en Revisión 2676/2003, case no. 1$)^{52}$}

We will begin with the insult to the national flag case, known as the "damned poet case" (caso del poeta maldito), or "the Sergio Witz case". ${ }^{53}$ Sergio Witz, a poet and university literature professor, published a poem entitled "Invitación (La patria entre mierda)". which means "Invitation (The Country Among Shit)", in a magazine called "Criterios" in April 2001. ${ }^{54}$ The problematic expression was contained in a section of the poem where the poet imagines himself using the Mexican flag as toilet paper. ${ }^{55} \mathrm{He}$ was charged under Article 191 of the Federal Penal Code, which allows for the imposition of either a fine, or up to 4 years of imprisonment, for anyone found guilty of insulting national symbols, including the national flag. ${ }^{56}$ This case reached the First Chamber (La Primera Sala) of the Mexican Court which addressed the constitutionality of the above provision. On October 5, 2005, a three justice majority opinion found against the poet, while two other justices dissented based on their belief that the poet was entitled to freedom of expression in this instance. ${ }^{57}$ As for his sentence, on May 7, 2008, a federal court found him guilty and ordered him to pay a fine of 50 Mexican pesos (approximately $2.28 \mathrm{US}$ dollars). ${ }^{58} \mathrm{Ar}$ -

52 Primera Sala de la Suprema Corte de Justicia de la Nación [SCJN], supra note 2.

53 See Cossío DíAz et al., supra note 38, at 19-24.

54 Pou Gimenez explains that this case was an easy case because it was about the verbal insult rather than physical, content rather than format of the poem, with a message of political dimension, not targeting any specific individual. Pou Giménez, supra note 35, at 924; Francisca Pou, El precio de disentir. El debate interno en la Corte, Isonomía. Revista de TeOría y Filosofía deL Derecho 187, 187-188 (2006).

55 The opening lines of the poem are as following: "I / clean my urine / on the flag / of my country / That rag / that dogs lie on / and that represents nothing". Translation from http://wwrw.banderasnews.com/0805/edat-poetfined.htm.

56 Pou Giménez, supra note 35, at 922-925. For comparable cases of burning national flags and other symbols in the United States of America, see Smith v. Goguen, 415 U.S. 566 (1974); Johnson v Texas, 491 U.S. 397 (1989); U. S. v. Eichman, 496 U.S. 310 (1990); U. S. v. O’Brien, 391 US 367 (1968); R. V. A. v. City of St. Paul, 505 US 377 (1992).

57 Octavio Díaz Alderet, Conjeturas acerca de la limitación a la libertad de expresión, por respeto a los simbolos patrios (caso del poeta maldito), Cuestiones Constitucionales 369, 370 (2007).

58 Carlos Avilés Allende, Multan a poeta que escribió versos contra la bandera, El UnIVERsal (May. 
ticle 191 of the Federal Penal Code states: ${ }^{59}$ "Article 191 of the Federal Penal Code. ${ }^{60}$ One who insults the coat of arms of the Republic or the national flag, in word or action, shall be imprisoned from six months to four years and/or fined 50 to 3,000 pesos." 61

The majority opinion, written by Justice José de Jesús Gudiño Pelayo, found Article 191 of the Federal Penal Code to be constitutional and did not breach the freedom of expression described in Articles 6 and 7 of the Mexican Constitution. ${ }^{62}$ The majority opinion held that the purpose of this provision is the dignity of the nation. ${ }^{63}$ They interpreted national symbols to be constitutionally protected based on Articles 3, 73, and 130 of the Mexican Constitution. Article 3 provides that education shall induce love for the homeland, and that insults to national symbols are therefore in opposition to that Article. ${ }^{64}$ Article 130 Paragraph 2(e) states that religious ministers may not offend any national insignia, although it does not prohibit the imposition of the same limitation on others. ${ }^{65}$ Article 73 Section XXIX-B empowers Congress to enact legislation regarding the elements and use of the national flag, coat of arms, and anthem. Referring to the legislative history, the majority opinion interpreted Article 73 as protecting national symbols from disrespectful acts at the constitutional level by criminalizing them. ${ }^{66}$ The majority opinion concluded that the protection of national symbols is recognized under the Mexican Con-

7, 2008), http://archivo.eluniversal.com.mx/notas/505032.html (Exchange rate of $1 \mathrm{USD}=22.01$ MXN on Mar. 13, 2020).

5936 OSCE states have criminal laws prohibiting insult and/or desecration of state symbols. Scott Griffen, Defamation and Insult Laws in the OSCE Region: A Comparative Study 2017, at 20-21.

60 On 13 April 2007, the Mexican federal government published a judicial reform that decriminalized the crimes of libel, defamation, and slander in the Federal Penal Code. However, Article 191 remained valid despite this reform. Ríos Ruiz, supra note 22, at 93.

61 Translation by me. The fine is equivalent to 2.27 to 136.38 US Dollars (Exchange rate of $1 \mathrm{USD}=22.01 \mathrm{MXN}$ on March 13, 2020)

62 Primera Sala de la Suprema Corte de Justicia de la Nación [SCJN], supra note 2, at 94-96.

Carbonell argues that the majority opinion should have announced that the questioned provision violates the principle of proportionality. Miguel Carbonell, Silenciar al disidente. La Suprema Corte del México contra la libertad de expresión, Isonomía 1, 13-14 (2006), http://werere.miguelcarbonell. com/artman/uploads/1/Ultrajando_a_la_Constituci_n.pdf(on file with author).

63 Primera Sala de la Suprema Corte de Justicia de la Nación [SCJN], supra note 2, at 93-97.

64 Primera Sala de la Suprema Corte de Justicia de la Nación [SCJN], supra note 2, at 97-98.

65 Primera Sala de la Suprema Corte de Justicia de la Nación [SGJN], supra note 2, at 98-99. López Salas explains that Article 130 is the only restriction on the state symbol in the Mexican constitution. Rafaela López Salas, El caso Sergio Witz: ‘un conflicto de derechos?, CuestioNES CONSTITUCIONALES 435, 437 (2007).

66 Primera Sala de la Suprema Corte de Justicia de la Nación [SCJN], supra note 2, at 99- 
stitution, and that fact justifies restricting freedom of expression. One may express ideas against national symbols, but may not insult them. ${ }^{67}$ In other words, the state may adopt measures to protect national symbols, including criminal punishment. ${ }^{68}$

The majority opinion also mentioned that using the word "ultraje (insult)" in Article 191 of the Federal Penal Code to describe the prohibited conduct is not vague and would not be applied arbitrarily. It declared that Article 191 does not breach the principle of legal certainty. ${ }^{69}$ The majority opinion held that there can be no doubt about what the lawmakers intended when they used the word "ultraje (insult)": it does not penalize dissenting opinions about national symbols, only insulting ones. ${ }^{70}$ The majority opinion did not reach the question as to whether the criminal punishment (a fine or up to 4 years of imprisonment) was disproportionate because a definitive sentence had not yet been declared in that case. ${ }^{71}$

The dissenting opinion, on the other hand, by Justice José Ramón Cossío Díaz and Justice Juan N. Silva Meza, concluded that freedom of expression was breached. The dissent stressed the importance of freedom of expression in a democratic society. ${ }^{72}$ In their view, when the legislature limits freedom of expression, the restriction should be necessary, proportional, and compatible with the principles, values, and constitutional rights of Mexican society. ${ }^{73}$ Regarding Article 191, the dissent first argued that Article 191 cannot be justified by any exception provided in Article 6 in the Mexican Con-

125. Article 73 XXI empowers the Congress to establish the crime and misdemeanors against the Federation and determine the penalties.

67 Primera Sala de la Suprema Corte de Justicia de la Nación [SCJN], supra note 2, at 123.

68 Primera Sala de la Suprema Corte de Justicia de la Nación [SCJN], supra note 2, at $97-125$.

69 Carbonell criticizes the majority opinion that the phrase is vague and it enables authorities to apply arbitrarily. Carbonell, supra note 63, at 12.

70 Primera Sala de la Suprema Corte de Justicia de la Nación [SGJN], supra note 2, at 125-127.

71 Primera Sala de la Suprema Corte de Justicia de la Nación [SCJN], supra note 2, at 127. Morales Sánchez and Carbonell criticized that the Mexican Court did not consider international human rights treaties signed by Mexico. Julieta Morales Sánchez, El Case Witz Rodríguez a la Luz del Derecho Internacional de los Derechos Humanos: Ponderación Constitucional, Libertad de Expresión y Limites, 9 Revista do Instituto Brasileiro de Direitos Humanos 127, 129 (2009); Carbonell, supra note 63, at 5-7.

72 Primera Sala de la Suprema Corte de Justicia de la Nación [SCJN], supra note 2, Voto de Minoría, at 1-6. Gama Leyva explains that the free circulation of ideas is important in a democratic society, as in the marketplace of ideas. Leopoldo Gama Leyva, La criminalización de la conciencia disidente (Caso del Poeta Maldito), 1, 2-3, https://wrere.academia.edu/20084996/La_ criminalizaci\%C3\%B3n_de_la_conciencia_disidente_Caso_del_Poeta_Maldito_.

73 Primera Sala de la Suprema Corte de Justicia de la Nación [SGJN], supra note 2, Voto de Minoría, at 6. 
stitution, that is, attacking the morals or rights of others, provoking crime, or disturbing the public order. ${ }^{74}$ Thus, they did not agree with the majority opinion that Articles 3, 73, and 130 of the Mexican Constitution protect the national flag and coat of arms. ${ }^{75}$ The dissent declared that it is incompatible with the Mexican Constitution that national symbols are protected by the criminal punishment of individuals since this requires the sacrifice of fundamental individual rights. ${ }^{76}$ The two justices also highlighted the severity of the potential punishment, specifically, the fact that the author of the poem could have been punished with up to 4 years in prison demonstrated that the legislature did not properly balance the constitutional limits to freedom of expression. ${ }^{77}$ Furthermore, they regarded the concept of "ultraje (insult)" to be vague, and combined with the disproportionate punishment, had a particularly negative and chilling effect on freedom of expression. ${ }^{78}$ The dissenting opinion concluded that Article 191 of the Federal Penal Code violated freedom of expression and that this Article should not be applied in this specific case. ${ }^{79}$

\section{The Insult to Authority Case in 2016 (Amparo Directo en Revisión 2255/2015, case no. 2) ${ }^{80}$}

The defendant in this case was criminally charged as a result of insulting police officers while they were performing an operation to remove street merchants in Mexico City on February 22, 2014. ${ }^{81}$ The criminal proceeding was

74 Primera Sala de la Suprema Corte de Justicia de la Nación [SCJN], supra note 2, Voto de Minoría, at 6-13.

75 Primera Sala de la Suprema Corte de Justicia de la Nación [SCJN], supra note 2, Voto de Minoría, at 13-16.

76 Primera Sala de la Suprema Corte de Justicia de la Nación [SCJN], supra note 2, Voto de Minoría, at 17.

77 Primera Sala de la Suprema Corte de Justicia de la Nación [SCJN], supra note 2, Voto de Minoría, at 17. Cruz Parcero also explains that the freedom to artistic creation also merits special protection. Cruz Parcero, supra note 40, at 434. Gama Leva posits that imposing criminal punishment on insulting certain value on state symbols violates the duty of neutrality of the state. Gama Leyva, supra note 73, at 7-8.

78 Primera Sala de la Suprema Corte de Justicia de la Nación [SCJN], supra note 2, Voto de Minoría, at 17-18.

79 Primera Sala de la Suprema Corte de Justicia de la Nación [SCJN], supra note 2, Voto de Minoría, at 19-20. Pou posits that the official opinion analyzed this article as an abstract norm while the dissenting opinion reviewed it in the light of concrete case. Pou, supra note 55, at 190191. Gama Leyva argues that article 191 of Federal Penal Code is a violation of the freedom of expression, freedom of conscience and the equality between citizens and their thoughts. Gama Leyva, supra note 73, at 9.

80 Pleno de la Suprema Corte de Justicia de la Nación [SCJN], supra note 6.

81 What she said to the police officers or the merchants in Spanish were as the following: 
initiated against her as a result of insulting a person in a position of authority under Article 287 of the Penal Code for Mexico City. She was sentenced to 10 months and 15 days of imprisonment and a fine of 2,691.60 Mexican pesos. She was granted imprisonment penalty substitution (sustitución de la pena de prisión). ${ }^{82}$ By a vote of 9 to 2, the Mexican Court held that Article 287 infringes upon Article 14 of the Mexican Constitution. That Article emphasizes the principle of legality, and when applied to the facts of this case, in the majority view, the word "ultraje (insult)" lacked certainty. Article 287 provides: "Article 287 of the Penal Code for Mexico City. Any person who insults an authority in the exercise of his/her functions, or with intent to do so, shall be imprisoned from six months to two years, and subject to a fine from 20 to 100 days of the minimum wage". ${ }^{83}$

The majority opinion, written by Justice José Fernando Franco González Salas, reviewed this provision under the principle of legality, which is enshrined in both Article 14 of the Mexican Constitution as well as Article 9 of the Inter-American Convention of Human Rights, both of which require criminal offenses be defined in a clear and precise manner. ${ }^{84}$ Among the elements that constitute the crime of insulting an authority, the behavior component of insulting (ultrajar) was carefully examined. ${ }^{85}$ The majority opinion held that the wording, even using a dictionary definition, covers a wide range of possible conduct. ${ }^{86}$ The majority opinion then interpreted that word in light of the entire provision and the context of the insulting expressions in the case. ${ }^{87}$ They concluded that even when considering the additional condition that the object of the insult must be an authority in the exercise of his functions did not sufficiently or reasonably limit the wide range of conduct that

"hijos de su pinche madre, yo me pongo porque me pongo, ustedes pinches gatos hambreados no van a impedir que mis comerciantes se instalen, no saben con quién se meten, yo conozco a los de la delegación y se van a quedar sin chamba." "ustedes pónganse, ustedes instálense, que estos pinches hambreados no nos van a impedir que nos pongamos." "pinche gato hambreado ni tú ni nadie nos va a quitar de aquí". Pleno de la Suprema Corte de Justicia de la Nación [SCJN], supra note 6, at 4.

82 Lennan introduces Coleman v. Power decision by the High Court of Australia that involves the use of insulting words against a police officer. Jo Lennan, Lawes Against Insult: History and Legitimacy in Coleman v Power, 10 LegaL Hist. 239 (2006).

83 Translation by me. The number of days in fine refers daily minimum wage. In this case the fine is of 20 to 100 days of daily minimum wage.

16 OSCE states have criminal laws prohibiting defamation or insult of state institutions. One of three types is prohibiting insult to public officials in the exercise of public office. Griffen, supra note 60, at 21-22

84 Pleno de la Suprema Corte de Justicia de la Nación [SCJN], supra note 6, at 18-27.

85 Pleno de la Suprema Corte de Justicia de la Nación [SCJN], supra note 6, at 28.

86 Pleno de la Suprema Corte de Justicia de la Nación [SCJN], supra note 6, at 29-31.

87 Pleno de la Suprema Corte de Justicia de la Nación [SCJN], supra note 6, at 32-33. 
would be subject to criminal sanction by the state. ${ }^{88}$ For these reasons, the majority concluded that Article 287 violates the principle of legality. ${ }^{89}$

Jorge Mario Pardo Rebolledo's dissenting opinion argued that Article 287 does not breach the principle of legal certainty nor freedom of expression. ${ }^{90}$ The dissent claimed that the concept of "ultraje (insult)" clearly establishes the conduct to be sanctioned since it specifies serious offenses and aggression, either verbal or physical, directed at an authority in the exercise of his/ her functions. ${ }^{91}$ The opinion also made reference to the decision in the insult to the national flag case previously discussed above, Amparo en Revisión 2676/2003. ${ }^{92}$ The dissent further argued that the need to maintain public order is a legitimate objective justifying a limitation on freedom of expression. Article 287 protects public order and security by criminalizing conduct that interferes with a public service, and therefore has a legitimate purpose. ${ }^{93}$

The concurring opinion, written by Justice Alfredo Gutiérrez Ortiz Mena, agreed with the conclusion of the majority, but stressed that Article 287 also infringes upon freedom of expression. ${ }^{94}$ The broad terms of that Article do not meet agreed upon standards of human rights and unfairly restrict freedom of expression. ${ }^{95} \mathrm{He}$ concluded that the Article is unconstitutional since it is overly inclusive and therefore detrimental to freedom of expression. In his view, the Article also failed to satisfy the strict test of proportionality. ${ }^{96}$

This decision signaled a change in insult law cases in Mexico. Although the Mexican Court had previously decided criminal punishment for insulting the national flag was constitutional in 2005, it decided that criminal punishment for insulting an authority infringes upon freedom of expression just eleven years later. ${ }^{97}$ Similar issues were also being raised regarding freedom of expression on the other side of the world, in South Korea.

88 Pleno de la Suprema Corte de Justicia de la Nación [SCJN], supra note 6, at 33-34.

89 Pleno de la Suprema Corte de Justicia de la Nación [SCJN], supra note 6, at 35.

90 Pleno de la Suprema Corte de Justicia de la Nación [SCJN], supra note 6, Voto Particular, at 1 .

91 Pleno de la Suprema Corte de Justicia de la Nación [SCJN], supra note 6, Voto Particular, at 3-4.

92 Pleno de la Suprema Corte de Justicia de la Nación [SCJN], supra note 6, Voto Particular, at 4

93 Pleno de la Suprema Corte de Justicia de la Nación [SCJN], supra note 6, Voto Particular, at 7 .

94 Pleno de la Suprema Corte de Justicia de la Nación [SCJN], supra note 6, Voto Concurrente, at 1 .

95 Pleno de la Suprema Corte de Justicia de la Nación [SCJN], supra note 6, Voto Concurrente, at 1 .

96 Pleno de la Suprema Corte de Justicia de la Nación [SCJN], supra note 6, Voto Concurrente, at 1 .

97 The Mexican Court also held that terms in Article 362 of the Penal Code for Mexico City, such as "extreme violence" and "disturbance of the public peace", are not sufficiently 


\section{Decisions of the Gonstitutional Gourt of Korea on INSUlt LaWs}

\section{Insult as a Criminal Offense Case in 2013 (2012Hun-Ba37, case no. 3)}

The first Korean decision is the case 2012Hun-Ba37 decided by the Korean Court on June 27, 2013, famously known as the "unheard-of nobody (듣보 잡, dutbojab)" case. ${ }^{98}$ This case arose out of a debate between two famous critics in South Korea, one being the progressive critic, Chin Joong-kwon, and the other, Byun Hee-Jae, a conservative critic. Chin had made online posts calling Byun an "unheard-of nobody (dutbojab)", which is a shortened form of "unheard-of and unseen nobody", a new online slang term that refers to a person or thing that is not well known. Chin was prosecuted on charges of insult for making posts insulting a person on his blog, as well as on the members' page of the New Progressive Party's website. He was also charged with defamation online. ${ }^{99}$ Chin was consequently sentenced to 3 million Korean won in fines by the trial court (approximately 2,457 US dollars) for charges of insult and other additional charges. ${ }^{100}$ Chin responded by filing a constitutional complaint to the Korean Court on January 25, 2012. The Korean Court decided by a vote of 5-3 that the insult law is constitutional and does not infringe upon any constitutional principles. The Article at issue provides as follows ${ }^{101}$ : "Article 311 (Insult) of the Criminal Act. A person who publicly insults another shall be punished by imprisonment or imprisonment without prison labor for not more than one year or by a fine not exceeding two million won". 102

precise and Article 362, therefore, is not in conformity with the principle of legality. Primera Sala de la Suprema Corte de Justicia de la Nación [SCJN], Amparo Directo en Revisión, $4384 / 2013$.

98 Constitutional Court [Const. Ct.], supra note 7. This decision has a precedent over the same Article but the second decision triggered more debate in the Korean society. The first decision is case 2009Hun-Ba199 decided on 30 June 2011. Constitutional Court [Const. Ct.], 2009Hun-Ba199, Jun. 30, 2011 (23-1B K.C.C.R. 337).

99 He was also charged for defaming a person by publicly disclosing false information for purpose of libel on the New Progressive Party website.

100 Exchange rate 1 USD = 1,220.60 Korean won on March 13, 2020.

101 For an analysis on court decisions, see Sung Soo Pyo, A Study on the Problems of the Insult Crime in The Criminal Code and the Way How to Fix Them, 64 Lawyers Association Journal 5, 13-16 (2015) (in Korean).

102 Translation from website of the Legislative Translation Center, http://elaw.klri.re.kr/ kor_service/lawViewedo? $h s e q=28627$ Elang $=E N G$. The amount is equivalent to 1,638 US dollars. Exchange rate 1 USD $=1,220.60$ Korean won on March 13, 2020. Park explains that criminalization of insulting expressions involving prosecution by prosecutor's office as in South Korea is not commonly found in other countries. Park, supra note 20, at 114 (in Korean). 
The majority first announced their determination that the Article did not violate the principle of clarity, which is required under the principle of legality. 103 They defined the term "insult" to be "an abstract judgment or an expression of derogatory emotion, unaccompanied by factual statements, that can undermine one's social reputation". ${ }^{104}$ After a consideration of both the legal interests and the legislative purpose behind penalizing the crime of insult, the Court concluded that it is reasonable to expect that an ordinary citizen with common sense, and a conventional sense of the law, to foresee what kind of acts are prohibited. ${ }^{105}$ The majority also added that "there is no concern for arbitrary interpretation by law enforcement agencies". 106

The majority then held that Article 311 of the Criminal Act does not violate the freedom of expression protected by the Korean Constitution. ${ }^{107}$ Applying a balancing test, the majority assigned more weight to the right to personality and reputation than to the right of freedom of expression in a case of insulting words. ${ }^{108}$ The majority ruled that in a case where an expression insulting someone's character is made publicly, "the victim's social status will be degraded and the potential for his/her life and development as a member of society will inevitably be affected". ${ }^{109}$ As a result, according to the majority view, the act of defamation using insulting words needs to be prohibited. The majority also considered as mitigating factors the fact that insult is punishable only after a victim files a complaint and has a relatively low statutory maximum. ${ }^{110}$ The opinion also considered that courts generally seek an adequate balance between freedom of expression and the protection of reputation by applying Article 20 of the Criminal Act which outlines "justifiable acts". This Article precludes punishment when an act is done in accordance with other Acts and statutes, or in pursuance of generally accepted business or social practices ("customary social act"). ${ }^{111}$ For the foregoing reasons, the majority concluded that Article 311 is not unconstitutional.

103 Constitutional Court [Const. Ct.], supra note 7, at 8-9.

104 Constitutional Court [Const. Ct.], supra note 7, at 9.

105 Constitutional Court [Const. Ct.], supra note 7, at 9.

106 Constitutional Court [Const. Ct.], supra note 7, at 9.

107 Constitutional Court [Const. Ct.], supra note 7, at 10-13.

108 Constitutional Court [Const. Ct.], supra note 7, at 12.

109 Constitutional Court [Const. Ct.], supra note 7, at 1, 10.

110 Constitutional Court [Const. Ct.], supra note 7, at 1, 11.

11 Constitutional Court [Const. Ct.], supra note 7, at 11-12. Park and Kim argue that when applied in insult law cases, the concept of customary social act in Article 20, is too vague and violates "void-for-vagueness" doctrine. Kyung Sin Park \& Khayeun Kim, The Legislative Purpose of the Insult Law and a Constitutional Critique of its Application by Courts, 10 Journal OF MEdia Law, Ethics and Policy Research 441, 458-462 (2011) (in Korean). Lee posits that Article 20 of the Korean Criminal Act should be widely applied to insulting expressions against public 
The dissent, comprised of three Justices (Justice Park Han-Chul, Justice Kim Yi-Su, and Justice Kang Il-Won), strongly criticized the majority opinion, declaring that the insult law violates freedom of expression. First, the dissent argued that "the scope of «insult» as an element of a crime is excessively broad, and that all negative or derogatory expressions directed at a person may amount to insult as they are likely to undermine one's social reputation". ${ }^{112}$ As a result, the insult law reaches "not only hateful cursing of someone humiliating enough to tear down his/her character, but also satirical, humorous literary expressions that use ridicule to expose and criticize the world, the twisting of negative intentions into the form of polite expressions, and newly coined words on the internet that are somewhat coarse". 113 The dissent argued that even expressions protected by the Constitution could be punished by the provision under review. ${ }^{114}$

The dissent emphasized that the criminal punishment of insults creates a chilling effect on freedom of expression. It "limits the possibility of raising issues in social communities and addressing them constructively through free exchange of different views and criticism". 115 They added, "it will threaten political and academic statements and restrain open debate if certain negative or critical expressions on sensitive issues used in political and academic debates are branded as insult". ${ }^{116}$ Furthermore, the dissent suggested the exercise of state authority to punish such a crime should be limited to the minimum. ${ }^{117}$ They also contended that criminal punishment is excessive because a less restrictive alternative exists. They explained that "an abstract judgment or a derogatory expression can be regulated through the self-correcting mechanism of civil society or by imposing civil liability". ${ }^{118}$ Finally, the dissent noted that penalizing insults violates international human rights standards. ${ }^{119}$ Ultimately, based on the foregoing reasons, the dissent concluded that Article 311 represented an unwarranted restriction of freedom of expression. ${ }^{120}$

\footnotetext{
figures through flexible interpretation. Seong Ki Lee, A Review of Criminality on the Criminal Contempt against Police Officers, 25 Han YANG Law Review 419, 432 (2014).

112 Constitutional Court [Const. Ct.], supra note 7, at 14.

113 Constitutional Court [Const. Ct.], supra note 7, at 14.

114 Pyo agrees with the dissenting opinion of this decision in the sense that the scope of insult law is excessively broad. Pyo, supra note 103, at 18.

115 Constitutional Court [Const. Ct.], supra note 7, at 2, 15-16.

116 Constitutional Court [Const. Ct.], supra note 7, at 2, 15-16.

117 Constitutional Court [Const. Ct.], supra note 7, at 16.

118 Constitutional Court [Const. Ct.], supra note 7, at 2, 16.

119 Constitutional Court [Const. Ct.], supra note 7, at 2, 17-18.

120 Cho agrees with the dissenting opinion in this case after analyzing the decision. Kuk Cho, De-criminalization of Defamation and Insult against Public Officials and Figures Regarding Public Issues, 25 Korean Journal of Criminology 9, 32-35 (2013) (in Korean).
} 


\section{Insult to the Republic of Korea Case in 2015 (2013Hun-Ka20, case no. 4)}

The second Korean decision that will be studied in this article concerns Article 104-2 of the Criminal Act. ${ }^{121}$ This provision was inserted in 1975 under the Kushin Constitution during the dictatorship of former President of the Republic Park Jung Hee. Article 104-2 criminalizes the behavior of any Korean national who endangers the security, interests, or prestige of the Republic of Korea outside of the country by insulting the Republic of Korea or its governmental bodies. ${ }^{122}$ The article targeted communications abroad as well as communications with foreigners inside the country in order to protect the international reputation and prestige of the Republic. After the democratic movement and the new Constitution adopted in 1987, this provision was abolished in December 1988. ${ }^{123}$

The defendant in this case had written a long poem in December 1975. The poem suggested that the Republic of Korea was a country under a dictatorship, that Koreans did not enjoy even a minimal level of fundamental rights and suffered merciless repression, and that the Korean government had sent soldiers to their death in the Vietnam War for a few pennies through secret negotiations. The author shared this poem with both Japanese and American foreigners in April 1976 and April 1977. He also published a translated version of his poem in a Japanese magazine in June 1977. He was charged with insulting the Republic of Korea under Article 104-2 and Presidential Emergency Decree No. 9. He was sentenced to 3 years of imprisonment in December 1977. His appeals to higher courts, including the Supreme Court of Korea, were denied and his sentence became final in September 1978. After 34 years, he petitioned for a retrial regarding his sentence at the Seoul Central District Court in April 2013. During the retrial, he filed a motion requesting a constitutional review of Article 104-2 of the Criminal Act that had been applied in his original case. The Seoul Central District Court granted his motion and sent this case to the Constitutional Court. The Korean Court declared that the previously abolished Article 104-2 of the Criminal Act had, in fact, been unconstitutional. ${ }^{124}$ Article 104-2 read as follows: ${ }^{125}$

121 For detailed analysis on Article 104-2, see Ho Gyeong Nam Gung, Nonmoon: Kukgamodokjoee daehan gochal [Study on Insult to the Nation], 33 SEOul Law Journal 180 (1992).

122 For composing elements of Article 104-2 and decisions, see Si-Myun Koh, "Profanation to the Republic" from the Perspective of Presidential Studies; Article 104-2 of the Criminal Act -Abolished in 1988- and Whether a Specific Article about the President by a Foreign Fournalist violates Article 70 of the Act on Promotion of Information and Communications Network Utilization and Information Protection, etc., Sabeophaengjung 2, 7 (2014).

123 Ruth Walden, Insult laws: An insult to Press freedom (World Press Freedom Committee Reston, VA. 2000), at 217.

124 Constitutional Court [Const. Ct.], supra note 8.

12519 OSCE states have criminal laws prohibiting insult of the state. Griffen, supra note 60 , at $19-20$. 
Article 104-2 (Profanation to the Republic, etc.) of the Criminal Act

(1) A Korean national who may or actually does undermine the safety, interest or dignity of the nation through insult, ${ }^{126}$ defamation, distortion, or dissemination of false facts of state institutions established by the government of the Republic of Korea or its Constitution, or through other means in a foreign territory shall be punished by imprisonment or imprisonment without prison labor for not more than seven years.

(2) A Korean national who commits acts specified in paragraph 1 by using aliens, foreign organizations, etc. in the territory of the Republic of Korea shall be punished as prescribed in paragraph 1 .

(3) The person who is guilty of acts as mentioned in paragraph 2 may also be deprived of his or her qualifications for not more than 10 years. ${ }^{127}$

The Korean Court, in a unanimous decision, held that the above article violated freedom of expression. The Court carefully reviewed whether the provision excessively restricted fundamental rights, using a four-pronged test based on the principle of proportionality: a) the restriction of a fundamental right should be have a legitimate purpose; b) the means employed should be appropriate to achieve the purpose; c) the restriction on fundamental rights should be the least restrictive; $d$ ) there should be a balance between the conflicting legal interests. ${ }^{128}$

The Korean Court first pointed out that although the purpose of Article 104-2 was to protect the security, interests, and prestige of the Republic, as stated in the legislative history, the Court questioned whether that was its genuine purpose. ${ }^{129}$ Second, the unanimous Court held that even if the claimed purpose of Article 104-2 had been genuine, criminal punishment is not an appropriate means of protecting the security, interests, and prestige of the Republic. ${ }^{130}$ In fact, Article 104-2 itself, by restricting freedom of expression, lessens the international reputation of the country and harms the interests and prestige of the Republic. ${ }^{131}$ Third, the Court pointed out that certain concepts contained in the provision, such as "any other means", "interests", or "prestige" of the Republic, are both ambiguous and excessively expansive. ${ }^{132}$ The Article also reached negative language and critical expressions

126 Although the text uses the word "profanes (모독 in Korean)", it is commonly interpreted as the same meaning as "insult (모욕 in Korean)". Nam Gung, supra note 123, at 181.

127 Translation from the decision.

128 Constitutional Court [Const. Ct.], supra note 8, at 161-163.

129 Constitutional Court [Const. Ct.], supra note 8, at 162. Nam Gung analyzed that the real purpose of this Article 104-2 intends to deter critiques against the then government. Nam Gung, supra note 123, at 183-185.

130 Constitutional Court [Const. Ct.], supra note 8, at 162.

131 Constitutional Court [Const. Ct.], 2013Hun-Ka20, Oct. 21, 2015 (27-2A K.C.C.R. 700), 705 .

132 Constitutional Court [Const. Ct.], supra note 8, at 162. Nam Gung argues that Article 
often used in political and academic debates, as well as satirical, humorous literary expressions that use ridicule to criticize the world. ${ }^{133}$ Additionally, the Court considered the following: that there are other laws that protect the security and independence of the Republic such as the Criminal Act, the National Security Act, and the Protection of Military Secret Act; that criminally punishing expressions that injure the prestige of the Republic is contrary to the spirit of democracy which both requires and guarantees the ability to freely criticize the government; and, that the Republic has sufficient resources and information available to adequately respond to false facts and malicious distortions without having to resort to criminally punishment. ${ }^{134}$ The Court also concluded that the Article breaches the rule of the least restrictive means. Lastly, the Court held that Article 104-2 does not meet the rule of balance between interests because the restriction of a fundamental right is excessive considering the importance of freedom of expression in a democratic society. ${ }^{135}$ For these reasons, the Court concluded that Article 104-2 violates freedom of expression.

As we have seen, the highest courts in both Mexico and South Korea have undertaken a focused examination of the issues surrounding the constitutionality of insult laws in their respective countries. It is now necessary to provide a comparative analysis of these decisions, focusing on the specific legal issues raised in each country's decisions.

\section{Comparative Analysis of the Decisions}

\section{Is Protecting the Dignity of the Nation a Legitimate Purpose of Insult Laws?}

In this section, I will examine the legitimacy of the various purposes offered in support of insult laws. Among the different purposes offered in the cases discussed previously in this article, I will focus here on the dignity of the nation. Is the dignity of the nation a valid constitutional interest requiring protection? If so, is it sufficient to justify the restriction the of an individual's fundamental rights? Is this, in fact, a legitimate purpose?

104-2 harms rather than promote the dignity of the nation because the harmful expressions against a nation should be responded by diplomatic and public and diplomatic relations of the government. Nam Gung, supra note 123, at 186.

133 Clooney and Webb posit that satirical expressions, as artistic expressions and social commentary, are given more protection than other expressions. Clooney \& Webb, supra note 4 , at 26 .

134 Constitutional Court [Const. Ct.], supra note 8, at 162-163.

135 Constitutional Court [Const. Ct.], supra note 8, at 163. 
The Mexican and Korean Courts have both tried to answer this question in cases arising as a result of provocative poems. The Mexican Court held that protecting the dignity of the nation was sufficient to justifiy criminal punishment for insulting the national flag (case no. 1). The prestige of the Republic of Korea was also the purpose used to justify criminalizing insults to the Republic (case no. 4).

Mexico, as a country, cherishes its national flag. In the insult to the national flag case from 2005 (case no. 1), the historical meaning of the national flag can be seen in the majority opinion's reference to the legislative discussions regarding Article 73 of the Mexican Constitution. The national flag of Mexico is generally considered to represent the tradition of fighting for justice and liberty. This purpose was not, however, unanimously accepted by the Court. The dissenting opinion argued that criminalization itself is against the very spirit of the Mexican flag. It held that a criminal norm that restricts the political meaning of the national flag goes far beyond any reasonable understanding of what is necessary to preserve public morals. ${ }^{136}$ Morales Sánchez emphasized that the Mexican Court's majority opinion did not provide a reason why the dignity of the nation justifies a limit of freedom of expression. ${ }^{137}$ And Lopéz Salas highlighted the fact that while the Mexican Constitution recognizes the honor of the nation, the official opinion of the Mexican Court did not distinguish between the honor and the dignity of the nation. ${ }^{138}$

While Mexico accepted that protecting or preserving the dignity of the nation was a legitimate purpose of insult law, the Korean Court questioned whether the dignity of the nation was the genuine purpose of their insult law in the case of insult to the Republic of Korea (case no. 4). It was clear in the motives of the draft bill that the purpose of this provision was to protect the dignity of the Republic of Korea, as well as the security and interests of the Republic. This official purpose was generally accepted by criminal law scholars at the time. ${ }^{139}$ However, in 2015, the Korean Court did not accept this official purpose as the genuine intent of this provision. In arriving at that decision, the Korean Court considered how this provision had not only been used to repress criticism and anti-governmental groups, but also the fact that it had been abolished in 1988 as part of the transition from dictatorship to democracy. Although the Korean Court did not offer further clarification, it could have announced that the actual intent of this provision was to oppress critics of both governmental policy and the President by blocking the free

136 Primera Sala de la Suprema Corte de Justicia de la Nación [SCJN], supra note 2, Voto de Minoría, at 8-9.

137 Morales Sánchez, supra note 72, at 128.

138 Salas posits that the principle of dignity exclusively protects the dignity of human beings. López Salas, supra note 66, at 443.

139 For detailed analysis about the purpose of Article 104-2, see Nam Gung, supra note 123, at 181-185. 
circulation of differing views, which had gone so far as to prevent communication with foreign media.

The historical and social context of the period when the law was effective, from 1975 to 1988 , should be considered in order to understand how the Korean Court came to discredit the alleged purpose of this provision. It was misused (or properly used if that was its real purpose) to silence critics of both governmental policies and the President. ${ }^{140}$ This offense was often called "profanation of the President" rather than "profanation of the Republic" due to the fact that it had been more widely applied to insults directed at the President. ${ }^{141}$ Although the wording of the provision purports to punish insulting expressions "outside of the country", it was interpreted by the Supreme Court of Korea to encompass the communication of insulting expressions with foreigners "inside the country", including communication with foreign journalists. ${ }^{142}$ Consequently, the elimination of this provision was proposed and debated immediately following the success of the democratic movement of 1987, which resulted in an amendment to the Constitution. This provision was finally deleted officially in December 1988 through the Special Committee for Democratic Development of the National Assembly.

Another factor to consider is that the unconstitutionality of the previously abolished insult law was not declared by the Korean Court until 2015, 40 years after the provision's initial adoption, and 27 years after having been abolished. Following the democratic movement, South Korea has developed into a vigorous democracy, ending decades of authoritarian regimes. There was no longer any external political pressure on the Korean Court to reaffirm the unconstitutionality of the restrictive clause. In fact, considering that the Korean Court, which was established by the last amendment of the Constitution, had gained the support of the public by eliminating the legacies of the past dictatorship regimes, it would be contrary to its own jurisprudencial independence if it had decided otherwise.

In my opinion, the dignity of the nation (or the Republic) is not a legitimate basis on which to restrict freedom of expression by criminal punishment. It does not belong to any category of justifiable restrictions of freedom of expression found in human rights charters or constitutions of other nations. As we have seen, generally accepted norms regarding human rights do permit restrictions on freedom of expression in cases where it conflicts with the rights (reputations) of others and the protection of national security, public order, or public morals. ${ }^{143}$ However, these do not include the dignity

140 Nam Gung points out that Article 104-2 could be applied to insulting expressions against the President as a private person not as a state authority. Nam Gung, supra note 123, at 191 .

141 Koh, supra note 124 , at 7.

142 Supreme Court of Korea [S. Ct.], 83Do515, Jun. 13, 1983.

143 Article 19 (3) of the ICCPR, Article 13 (2) of the ACHR, Article 6 of the Mexican Constitution, and Article 21 paragraph 4 of the Korean Constitution. 
of the nation. An expression insulting a nation does not harm the rights or reputation of any third person. Nor does it harm the security of a country or disturb the public order unless it involves violence. ${ }^{144}$ The meaning and extent of public morals may be different in each country depending on the social, philosophical and religious understanding of its citizens. ${ }^{145}$ In other words, whether the dignity of the nation is an element of public morals may be differently interpreted. There is sufficient room for discretion on the part of the jurists in each country on this issue. From my point of view, limitations based on public morals would be proper, for example, when regulating the level of obscenity with respect to publications directed at minors, but would not be proper with respect to regulating purely verbal expressions that in no way promote or lead to violence. Expressions insulting the dignity of the nation, in fact, do no harm. ${ }^{146}$

It is, in fact, the criminalization of "insulting" expressions directed at the national flag, national authorities, or the nation itself that does harm to the dignity and prestige of the country. ${ }^{147}$ Incorporating these types of criminal provisions into the penal code inevitably damages a country's reputation for guaranteeing freedom of expression. Indeed, when the insult to the national flag case was decided by the Mexican Court, the decision was criticized for not allowing sufficient space in the political discourse for a disrespectful poem. Criminalizing insult laws is widely regarded as being overly restrictive of freedom of expression since enforcement of these provions is often used to suppress only those opinions and views that are in opposition to the government. The Korean case of insult to the Republic is a good example of this. The criminal punishment of insulting expressions against the nation had been misused to the point that the purported official purpose, in that case protecting the dignity of the nation, was rejected by the Korean court.

Furthermore, these types of insult laws do not meet international human rights standards. The Human Rights Committee states that to lawfully restrict freedom of expression for any cause, "the precise nature of the threat, the necessity and proportionality of the specific action taken must be clearly demonstrated "in specific and individualized fashion". ${ }^{148}$ In the above cases, it would be difficult to establish that the poems caused a direct and immediate threat to the dignity of either Mexico or South Korea. Accordingly, the use of

144 Morales Sánchez posit that the poet in the national flag case did not harm any other person or moral, did not provoke any crime, and did not disturb public order or peace. Morales Sánchez, supra note 72, at 129.

145 Human Rights Comm., supra note 14, para 32.

146 Cruz Parcero posits that it is fallacious to argue that insulting national symbols harms the dignity of the nation because there is no damage to prove in this case. Cruz Parcero, supra note 40 , at 430 .

147 See also Nam Gung, supra note 123, at 186.

148 Human Rights Comm., supra note 14, para 35. 
criminal punishment, which should only be used as a last resort, is neither a necessary nor proportional means by which to regulate disrespectful expressions. ${ }^{149}$

In sum, I do not believe that the dignity of the nation is a legitimate cause to restrict insulting expressions. Nevertheless, we still live in a world, even in formally democratic societies, where political leaders and public officials are often tempted to keep people quiet and to avoid criticism. Often, they will use other insult laws, some intended for entirely different purposes, to block this criticism. I will analyze insult laws with other purposes in the next section.

\section{Insult to Public Officials: More Tolerant or More Strict?}

The dignity of the nation is not the only interest that insult laws attempt protect by criminalizing insulting expressions. In this section, I will review how other insult laws restrict expressions against public officials and how they conflict with the principle that guarantees the free circulation of ideas and expressions regarding public figures and public concerns.

In Mexican law, expressions against public officials are regulated in order to protect the exercise of a public function. Article 287 of the Penal Code for Mexico City in the insult to the authority case (case no. 2) is not the only law that regulates insults directed against public officials. Article 189 of the Federal Penal Code imposes one to six years' imprisonment in addition to that which corresponds to the crime committed. ${ }^{150}$ According to the Special Rapporteur, although Article 189 "does not refer specifically to crimes of disrespect, or desacato, against public officials, but rather to any crime against a public official, the effect is to make the penalties greater for criminal defamation, libel, and slander when these are committed against public officials than against private individuals". ${ }^{151}$ These provisions punish an offense against a public servant, agent, or authority in the exercise of his or her functions.

149 Clooney and Webb argue that proportionate civil penalties should be imposed instead of prison terms. Clooney \& Webb, supra note 4, at 40-41. The dissenting opinion of the National flag case is rooted in dominant concepts in international human rights jurisprudence. Pou, supra note 55, at 196. Salas argues that penal punishment is an excessive means to limit the freedom of expression in a plural and democratic society. López Salas, supra note 66, at 446.

150 Article 189 of the Federal Penal Code

Anyone committing an offense against a public servant of agent of authority in the act of lawfully carrying out his duties or by reason of them shall be subject to one to six years' imprisonment in addition to that which corresponds to the crime committed.

Translation from the report of the Special Rapporteur for freedom of expression on desacato laws (2000), at 65, http://werw.oas.org/en/iachr/expression/docs/reports/desacato/Desacato\%202000. $p d f$.

151 Special Rapporteur for freedom of expression on desacato laws, supra note 152, at 65, para. 22. 
Criminal punishment for insulting expressions against public officials purports to protect the exercise of some public function.

In Korean law, expressions directed against public officials are often punished because they infringe upon the honor of the public official as a private person. ${ }^{152}$ After the insult to the Republic provision was abolished in 1988, no subsequent law purported to officially punish insulting expressions directed against public officials in general. ${ }^{153}$ However, Article 311 of the Criminal Act does punish insulting expressions that violate the honor of another person, as in case no. 3. Although this provision aims to protect private persons, it has been increasingly used to protect public officials, especially police officers. ${ }^{154}$ According to the Annual Reports of the Prosecutor's Office about Crime Analysis from 2000 to 2016, the number of defamation and insult cases (crimes under Part II Chapter XXXIII, Crimes against Reputation) has increased over time, as shown in Figure 1 below. ${ }^{155}$ The increase is related to the fact that the police officers began to file cases as victims of insulting expressions after 2007. ${ }^{156}$ At that time, the Seoul Central District Police issued directives to file insulting expressions directed against police officers, and a drunken citizen was arrested for the first time for insulting a police officer in April 2007. ${ }^{157}$ Individuals who have been charged for insulting police officers and subsequently arrested on those charges are increasingly submitting petitions to the National Commission of Human Rights in Korea. ${ }^{158}$ The number of cases filed by public officials increased sharply beginning in 2007, but decreased again after 2015. ${ }^{159}$ One explanation for

152 Kim and Moon discuss about the status of police officers in insult law cases against them: as a private person and as a public officer. Min-Jung Kim and Jun-Young Moon, Reestablishment of review structure of insult law cases against police officers, 8 BuBHAKPYUNGRON 408, 437-440 (2018).

153 The exception to this would be the criminal punishment of insults in the National Assembly, courts or army in Korea. Jin-soo Chung et al., A Study on the Korean Courts' Standards for Defamation and Insult : Focused on Defamation and Insult Decisions DURING THE Last Ten Years (2005-2015) (Korean Institute of Criminology. 2015), at 65-67 (in Korean).

154 Cho analyzed cases where Artcle 311 of the Criminal Act was applied to insulting expressions against public figures. Cho, supra note 122, at 29-35.

155 Kim and Moon show that insult cases drastically increased during past 10 years. Kim \& Moon, supra note 154, at 414-416.

156 For court decisions of insult law against police officers, Kim \& Moon, supra note 154, at 417-427.

157 Kang Ah-yeon, First Arrest for Insulting Police Officer, Seoul Shinmun (Apr. 23, 2007), http://wrere.seoul.co.kr/news/newsView.php?id=20070423007006. Constitutional Court [Const. C..], supra note 7 , at 17 .

15890 petitions concerned those cases charged of insulting police officers from 2011 until 27 Aug 2014. Lee, supra note 113, at 420.

159 According to the 2012 Annual Report of the Prosecutor's Office, in 2000 the number of cases filed involving insult amounted to 1,858 and 532 individuals were indicted, and in 
Esta revista forma parte del acervo de la Biblioteca Jurídica Virtual del Instituto de Investigaciones Jurídicas de la UNAM

this decrease could be the public debate that arose concerning the excessive use of arrest for insulting police officers. The National Commission of Human Rights also recommended the Commissioner-General of the Korean National Police Agency address problems with the relevant police procedures in December 2014. ${ }^{160}$

\section{Figure 1. Number of Grimes Against Reputation and the Number of Cases where Victims are Governmental Institutions or Public Officials ${ }^{161}$}

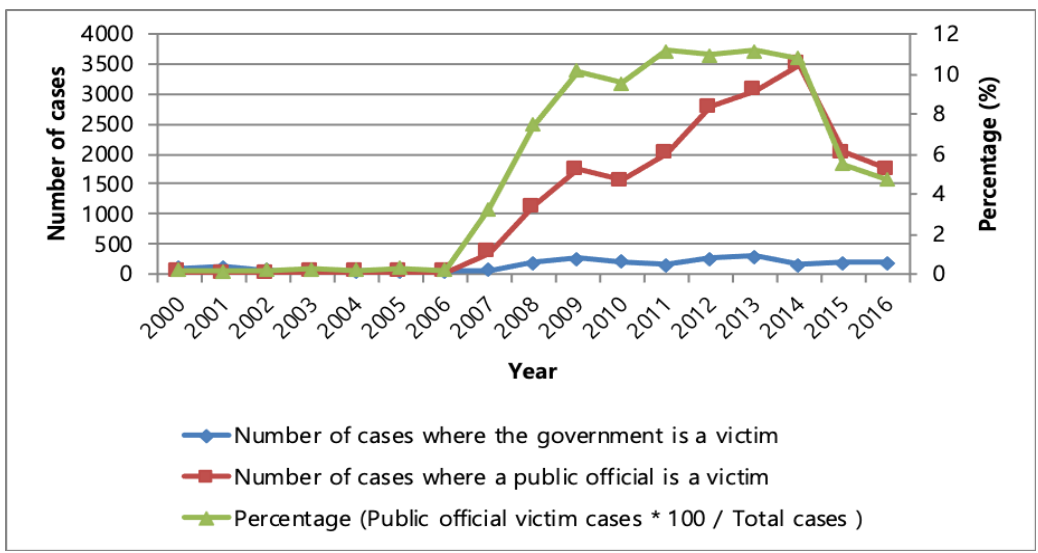

An example of the misuse of this law was the criminal punishment of a 29-year-old Army officer who criticized the then-President of the Republic of Korea, Lee Myung-Bak. He was charged for insulting a military superior by posting insulting expressions against the President of the Republic of Korea on his twitter account. The court considered the President of Republic as his military superior because the President is the supreme commander of the

2011 a total of 11,839 cases were filed and 6,260 were prosecuted. There could be many reasons for the 10 fold-increase in the number of prosecuted individuals within 11 years. Constitutional Court [Const. Ct.], 2013Hun-Ba1 11, Feb. 25, 2016 (233 K.C.C.G. 339)

160 Yonhap News Agency, Human Rights Commission of Korea, "Concerns about Human Rights Violations in cases of Arrests for Insulting Police Officers" (Dec. 9, 2014), http://werwre.yonhapnews.co.kr/ bulletin/2014/12/09/0200000000AKR20141209088800004.HTML?input $=1195 \mathrm{~m}$. For problems for prosecuting insults against police, see Lee, supra note 113, at 425 .

1612001 Crime Analysis, at 246; 2002 Crime Analysis 246; 2003 Crime Analysis, at 246; 2004 Crime Analysis, at 256; 2005 Crime Analysis, at 286; 2006 Crime Analysis, at 286; 2007 Crime Analysis, at 288; 2008 Crime Analysis, at 288; 2009 Crime Analysis, at 314; 2010 Crime Analysis, at 372; 2011 Crime Analysis, at 372; 2012 Crime Analysis, at 372, 2013 Crime Analysis, at 372; 2014 Crime Analysis, at 372; 2015 Crime Analysis, at 580; 2016 Crime Analysis, at 584; 2017 Crime Analysis, at 584, available at the website of Prosecutors' Office (Korea), http://werere.spo.go.kr/site/spo/crimeAnalysis.do. 
armed forces. He was subsequently sentenced to 6 months in prison and a year of probation. In 2016, the Korean Court affirmed the constitutionality of Article 64 Paragraph 2 of the Military Criminal Act which punishes insults of a superior officer. ${ }^{162}$

Thus, expressions against public officials are still subject to criminal punishment by a separate legal provision, as in Mexico, or by extending the application of insult laws intended to protect private individuals to public officials, as in Korea. Do public officials merit more protection from insulting expressions, or should they be more tolerant of insults? If public officials are more protected from insulting expressions, is this not a breach of the principle of equality, namely, between public officials and private individuals? ${ }^{163}$

Different values may come into play regarding insult laws. There are two different perspectives that could either mitigate or aggravate the seriousness of insulting public officials when compared to insulting private individuals depending on which perspective is applied. On the one hand, the fact that the victims is a public official is a mitigating factor because it allows for free expression of criticism against them. ${ }^{164}$ The fact that the expression is about a public figures or a public concern may preclude culpability. ${ }^{165}$ For example, Article 310 of the Korean Criminal Act states that defaming expressions are not punishable when they are true and solely for the public interest. ${ }^{166} \mathrm{On}$ the other hand, the fact that a victim is a public official can be an aggravating factor because the insulting expressions not only harm the reputation of the victim, they also interfere with the exercise of a public function. The separate legal provisions that criminalize expressions against public officials allowing additional punishment, such as Article 189 of the Mexican Federal Penal Code, are based on this rationale. ${ }^{167}$

I argue that the rationale to protect a public function does not justify the criminal punishment of insulting expressions directed against public officials.

162 Constitutional Court [Const. Ct.], 2013Hun-Ba111, Feb. 25, 2016 (233 K.C.C.G. 339)

163 Public officials enjoy the resources to investigate and prosecute their complaints. Winfield \& Mendoza, supra note 33, at 7.

164 Yanchukova, supra note 3, at 866-868.

165 Cho argues that defamation against public figures should be decriminalized. Cho, supra note 122 , at 23-26.

166 Article 310 of the Criminal Act of Korea

If the facts alleged under Article 307 (1) are true and solely for the public interest, the act shall not be punishable.

Kim posits that the exception clause of Article 310 should be also applicable to insult law considering its defamation character. See Sang-Ho Kim, Insult and Slander in Criminal Law, JusTICE 52, 69 (2008) (in Korean). Cho argues that Article 310 should be applicable to insult law. Cho, supra note 122, 36-37.

1679 OSCE states have criminal laws that provide harsher criminal punishment to defamation or insult against a public official than those against a private person. Griffen, supra note 60 , at 13 . 
It runs contrary to the principle that expressions concerning public figures and public concerns should enjoy broad constitutional protection given the importance of the free circulation of opinions and views in a democratic society. ${ }^{168}$ This principle is affirmed by the Mexican and Korean Constitutions as well as by both universal and Inter-American human rights standards.

The rationale that insulting expressions may disrupt a public function should not restrict expressions directed against public officials. Expressions that amount to "insults" are intrinsically merely an expression. When insult remains an expression such as a poem in a magazine, or a blog post on the internet, no public function is disturbed by the expression itself. If an expression involves violence that would actually and materially interrupt the exercise of a public function, other criminal provisions typically apply.

We can imagine that an assault on a police officer may be punished more severely than an assault on a private person, as it would actually disrupt the execution of the officer's official duties. However, the same logic cannot, and should not, be applied to mere expressions. Insulting words towards a police officer are not directed to him as a person but as an agent of the public entity. ${ }^{169}$ It does not harm his personal reputation. There is no damage, material or symbolic, to the public function from criticism that is merely unpleasant, disrespectful, or insulting. ${ }^{170}$

As a result, I argue that public officials should be required to tolerate a greater degree of insult than private individuals. The protection of public officials via the imposition of criminal punishment impedes societal aspirations for true freedom of expression necessary to a democratic society. The protection of a public function or the honor of a public official should not defeat the higher objective of permitting legitimate criticism of public officials and public concerns.

\section{Constitutional Standards: "Insult", Too Vague or Too Broad?}

I have examined why insulting expressions directed against public officials should be protected under national constitutions. I will now move on to the

168 "The rationale behind desacato laws reverses the principle that a properly functioning democracy is indeed the greatest guarantee of public order". Inter-Am. Comm'n H.R., supra note 26 .

169 Lee argues that whether expressions are against police officers as a private person or as public officer should be considered. Lee, supra note 113, at 426-428.

170 The Constitutional Court of Hungary declared unconstitutional Article 232 of the Penal Code that prohibited defamation and libel against public officials in the same way as those committed against private persons. The Court stated that the protection granted by criminal law to the honor of public authorities and officials is unconstitutional in that a greater degree of insult may be tolerated than in the case of private persons. Alkotmrinybir6sdg (AB) [Constitutional Court], Jun. 21, 1994, 36/1994(VI. 24.)AB (Hung.), https://hunconcourt.hu/uploads/ sites/3/2017/11/en_0036_1994.pdf. 
constitutional standards that were used in these four decisions, namely, the principle of legality (clarity) and freedom of expression.

The constitutional standards that were used by both the Mexican and Korean Courts are the principle of legality (clarity) and freedom of expression. However, the two constitutional courts applied these principles in different ways and reached different conclusions. In short, when the Mexican Court declared insults to authority to be unconstitutional, the Court based their reasoning on the principle of clarity, which is derived from the principle of legality. Meanwhile, when the Korean Court declared insults to the Republic to be unconstitutional, that Court based its reasoning on freedom of expression. A table of the conclusions of the two Courts related to each constitutional standard, the principle of clarity and freedom of expression, is shown as follows:

\section{Table 1. Conclusions of the Two Courts on Each Constitutional Standard}

\begin{tabular}{|l|l|l|l|l|}
\hline \multirow{2}{*}{} & \multicolumn{2}{|c|}{ Mexican Court } & \multicolumn{2}{c|}{ Korean Court } \\
\cline { 2 - 5 } & $\begin{array}{c}\text { Insult to the } \\
\text { national flag } \\
2005\end{array}$ & $\begin{array}{c}\text { Insult to the } \\
\text { authority } \\
2016\end{array}$ & $\begin{array}{c}\text { Insult as criminal } \\
\text { offense 2013 }\end{array}$ & $\begin{array}{c}\text { Insult to the Republic } \\
2015\end{array}$ \\
\hline $\begin{array}{l}\text { Principle of } \\
\text { clarity }\end{array}$ & $\begin{array}{l}\text { "insult" } \\
\text { Not vague } \\
\text { Vague } \\
\text { violation of } \\
\text { the principle of } \\
\text { legality }\end{array}$ & $\begin{array}{l}\text { "insult" } \\
\text { Not vague }\end{array}$ & $\begin{array}{l}\text { Vague } \\
\text {-interests", "prestige" } \\
\text { viom of expression }\end{array}$ \\
\hline $\begin{array}{l}\text { Freedom of } \\
\text { expression }\end{array}$ & $\begin{array}{l}\text { Legitimate } \\
\text { restriction }\end{array}$ & (no review) & $\begin{array}{l}\text { Not excessive } \\
\text { restriction }\end{array}$ & $\begin{array}{l}\text { Excessive restriction } \\
\text { violation of free- } \\
\text { dom of expressions }\end{array}$ \\
\hline
\end{tabular}

Beginning with the principle of clarity, the provisions under review used the verb "insult" to describe the conduct which exposes a person to criminal liability. However, the two Courts reached their decisions differently in each case. In Mexico, the principle of clarity was more carefully discussed in the 2016 case of insult to authority (case no. 2) than in the 2005 case of insult to the national flag (case no. 1). In the insult to the national flag case (case no. 1), the First Chamber of the Mexican Court did not find "ultraje (insult)" to be a vague concept. ${ }^{171}$ However, in 2016 (case no. 2), the Full Chamber of the same Court expressed a completely different view of the same concept. The Mexican Court found the concept too vague and determined the questioned

171 Primera Sala de la Suprema Corte de Justicia de la Nación [SGJN], supra note 2, at 125127. Gama Leyva also argues that "insult (ultrajar)" in the national flag case is a vague concept. Gama Ley-va, supra note 73, at 10. 
provision to be unconstitutional. The semantic definition of the word covers a broad spectrum of conduct, and other phrases in the provision did not sufficiently or meaningfully limit its application. The Court concluded that this concept was so expansive that judicial and administrative authorities may apply the concept arbitrarily. ${ }^{172}$

The Korean Court, on the other hand, did not find "모욕 (insult)" to be a vague concept in the 2013 case of insult as a criminal offense. ${ }^{173}$ The Korean Court considered the dictionary definition as well as various academic interpretations by criminal law professors. The Korean Court held that conventional wisdom and sound common knowledge could determine whether a certain expression is an insult in any specific individual case. The Court also mentioned that there is no concern that a law enforcement agency will interpret insult law arbitrarily because the Supreme Court of Korea has provided an objective standard for interpreting the meaning of insult.

Regarding the principle of clarity, the standard applied by the Mexican Court appears to be more strict than that used by the Korean Court. The Mexican Court decided the word "insult" was too vague, while the Korean Court held that the same word is not vague and would not be applied arbitrarily by authorities. While both Courts mentioned that the common sense understanding of the public regarding insult would be considered by the authorities, the two Courts arrived at different conclusions. I do not believe this is because the word "insult" is more specific in Korean than in Spanish. Nor is the different conclusion explained by the fact that Korean authorities interpret and apply the questioned provisions more carefully than Mexican authorities. (We have seen that "unheard of nobody" is considered an insult in South Korea.) From my point of view, the word "insult" in Korean does, in fact, leave room for Korean authorities to interpret the term arbitrarily.

The different result of the Korean Court is better explained by the fact that the Korean Court tends to approach the same problem from the perspective of freedom of expression rather than the principle of clarity. When they decided the insult law was unconstitutional, the Korean Justices stated it was too broad rather than too unclear. The issue of vagueness in insult law is often considered a violation of freedom of expression, rather than a violation of the principle of clarity or legality. In the 2015 decision regarding insult to the Republic, the Korean Court considered that expressions such as "interests", "prestige," and "any other means" to be vague and, thus, too broad. ${ }^{174}$ The Court considered vagueness in terms of freedom of expression, rather than as a separate constitutional standard of the principle of legality. The Court decided that the norm breached the least restrictive means rule, which

172 Pleno de la Suprema Corte de Justicia de la Nación [SCJN], supra note 6, at 28-35.

173 For details about the meaning of "Insult", see Pyo, supra note 103, at 9-11.

174 The terms are widely used in Korean legal text. This would entail the Court to decide with more caution when deciding whether they are vague or not. 
is a consideration within freedom of expression jurisprudence. ${ }^{175} \mathrm{Also}$, in the insult as a criminal offense case in 2013, the dissenting opinion pointed out that the scope of "insult" as an element of a crime was excessively broad. The dissent argued that all negative or derogatory expressions could amount to insult as they are likely to undermine one's social reputation. As a result, the dissent warned that

...not only hateful cursing of someone humiliating enough to tear down his/ her character, but also satirical, humorous literary expressions that use ridicule to expose and criticize the world, or the twisting of negative intentions into the form of polite expressions, or newly coined words on the internet that are somewhat coarse, etc., are also punishable as a crime of insult. ${ }^{176}$

Another factor that affected the two Courts' differing approaches is the logical order of the two constitutional standards. In the Mexican Court's majority opinion in the 2016 insult to authority case (case no. 2), after finding the questioned provision unconstitutional based on the principle of clarity, that Court did not review the substantive issue of freedom of expression. It held that the petitioner had focused on the principle of legality and that this principle would have been examined first even if the freedom of expression principle had been argued. The Court referred to the fact that the InterAmerican Court had also analyzed the principle of legality first when a violation of freedom of expression was argued. ${ }^{177}$ In contrast, the Korean Court did not review the principle of clarity when it decided that the insult to the Republic law breached the principle of freedom of expression. In practice, the Korean Court also reviews the principle of legality prior to the consideration of substantive constitutional rights. However, when it declares a law unconstitutional, the Korean Court finds it sufficient to refer to the strongest reason; it is not obliged to review other principles and constitutional rights that may be raised in the case. Furthermore, from a practical standpoint, the Korean Court may prefer to review freedom of expression over the principle of clarity in order to restrict the impact of the decision on possible future cases. The Korean Court seems to consider that if it were to find a certain expression vague, it might then encounter the same constitutionality challenge

175 The dissenting opinion of the insult as criminal offense case mentioned that "insult" is too broad rather than too vague.

176 Constitutional Court [Const. Ct.], supra note 7, at 14. Satirical expressions are protected in other international human rights courts. The European Court of Human Rights held that the conviction for insulting the then French President Sarkozy by holding a placard written "Casse toi, pauv' con (Get lost, you sad prick)" is a violation of this person's freedom of speech. Eon v. France, App. No. 26118/10, (Eur. Ct. H.R. Mar. 14, 2013). Clooney \& Webb, supra note 4, at 26.

177 Pleno de la Suprema Corte de Justicia de la Nación [SGJN], supra note 6, at 35-41. 
arising from any law that contains the same word. ${ }^{178}$ If it declares "insult" to be too vague, then all laws that include the word "insult" could be considered too vague and thus unconstitutional. To avoid expanding claims of violations of the principle of legality, it may prefer to declare a specific law to be in breach of freedom of expression.

The broadness and vagueness of any law regulating expressions are, in fact, closely related. Both broad and vague terms in insult laws may violate the principle of clarity derived from the principle of legality. They may also breach substantive rights of freedom of expression at the same time. In my opinion, the latter perspective deals more closely with the core issue of these types of cases. The enhanced protection for expressions directed against public officials goes to the very essence of freedom of expression - namely, its significance in a democratic society. Herein lies the principal reason why public officials should tolerate a greater degree of insult.

Another point that should be discussed regarding freedom of expression is the "chilling effect" that such a restriction introduces. ${ }^{179}$ Specifically, criminally punishing insults chills freedom of expression. ${ }^{180}$ The possibility of arrest, indictment, and punishment deters individuals from freely expressing opinions that are not aligned with a governmental entity, whether it be a person, institution, or symbol. It restrains the open and free exchange of opinions and criticism because dissenting opinions often use negative, derogatory, and disrespectful expressions that could amount to insult. This harms the very spirit of democracy.

This impediment to open democratic debate is most certainly aggravated by the threat of criminal punishment. ${ }^{181}$ Criminal punishment is one of the state's strongest powers and should not only be used as a last resort, but should also be confined to a minimum. If there is any need to regulate a derogatory expression in order to protect either a private person's honor or the exercise a public function, it should be regulated through a self-correcting mechanism of civil society or the imposition of civil liability. These are more appropriate mechanisms for use in a democratic state which purports to guarantee freedom of expression as a fundamental goal in and of itself. When civil enforcement mechanisms are available, criminal punishment of insulting expressions

178 The Criminal Act of Korea has six other provisions that include the wording "insult". Also the Word "insult" is found in other criminal provisions in the Military Criminal Act and the Act on Testimony, Appriasal, etc. Before the National Assembly. Chung et al., supra note 155 , at 65-67.

179 Winfield and Mendoza argue that criminal proceedings on insult against public officials produce chilling effect. Winfield \& Mendoza, supra note 33, at 7.

180 Yanchukova, supra note 3, at 893. Park and Kim also posit that insult law punished by Article 311 of the Criminal Act in South Korea seriously creates chilling effect on free expressions. Park \& Kim, supra note 113, at 458-462.

181 Yanchukova, supra note 3, at 893. 
is neither a necessary nor legitimately proportional restriction. Rather, it is an excessive restriction which violates the essence of freedom of expression.

\section{Conclusions and Suggestions}

In conclusion, criminally punishing insulting expressions against public officials violates freedom of expression. The dignity of the nation is not a legitimate interest upon which to base the restriction of insulting expressions. Nor do other purported interests, such as the protection of public function or the honor of a public official, justify this excessive restriction on freedom of expression. Public officials should be required to tolerate a greater degree of insult than private individuals. Thus, the criminal restriction of expressions directed against public officials is contrary to the the underlying principle of freedom of expression so important in a democratic society.

Based on the above conclusions, I argue that criminal punishment for expressions directed against public officials and entities should be removed from the criminal code. ${ }^{182}$ The insult law regulating expressions insulting to the national flag, such as Article 191 of the Federal Penal Code of Mexico, or Article 105 of the Criminal Act of Korea (Profanation of National Flag or National Emblem), should be abolished.

Furthermore, the provisions that criminalize insults to authority should be also removed. There are two ways this could be done. For example, Article 287 of the Penal Code for Mexico City punishes insults to public officials. This provision has been declared unconstitutional by the Mexican Court and was not applied in the case under examination, but it is still present in the Penal Code for Mexico City. A second instance is Article 189 of the Federal Penal Code of Mexico which imposes aggravated sentences of imprisonment when a crime is directed against a public official. Both of these provisions should be amended so that they do not apply to insult law (as well as libel and defamation).

If a certain act actually interferes with the exercise of a public function and there is a legitimate need to punish those acts, then they should be punished for that specific reason, not for insult to authority. For example, Article 136 of the Korean Criminal Act specifically provides criminal punishment for a person who uses violence or intimidation against a public official engaged in the performance of his duties. ${ }^{183}$ Article 311 of the Korean Criminal Act, a general provision defining insults against private persons as a criminal of-

182 Yanchukova, supra note 3, at 894.

183 Article 136 (Obstruction of Performance of Official Duties) of the Criminal Act of Korea:

(1) A person who uses violence or intimidation against a public official engaged in the performance of his duties shall be punished by imprisonment for not more than five years, or five not exceeding ten million won. 
fense, should not be applied to expressions against public officials. ${ }^{184}$ If a disturbance occurs, Article 136 of the Korean Criminal Act should apply instead of Article 311.185 The Korean authorities should not deviate from Article 136, a special law, by applying a general law, Article 311, which has less stringent requirements for criminal punishment. ${ }^{186}$

Legislative amendments to the criminal codes would be an unequivocal way to resolve these problems. If those changes are not possible in the near future, I argue that the judiciary and governmental authorities should not apply insult laws in criminal cases regarding expressions directed against public officials. Both countries have constitutional theories accepted by their highest courts which are designed to protect expressions against public officials. These theories should be applied to insult laws rather than criminally punishing expressions against public officials. ${ }^{187}$

Insulting a nation or a public official should not be criminalized. The legislative amendments and judicial interpretations that i suggest are neither impossible nor impractical. Mexico and South Korea are societies with open public forums that could adequately accommodate and respond to insulting expressions. Additionally, there are other legal mechanisms and social mechanisms better suited to regulate such expressions if there is a need. Eliminating insult laws would not harm, but rather strengthen, democratic society in both Mexico and South Korea.

The constitutions of Mexico and South Korea do protect freedom of expression. The high courts in the two countries interpret their respective constitutional provisions to acknowledge the importance of freedom of expression in a democracy. Nevertheless, there exist problematic laws that prohibit expressions that insult the state or public officials in both countries. The high courts have reached different conclusions in two cases in each country: one in favor of freedom of expression, the other in favor of other values, such as the dignity or proper functioning of the state. First of all, insult laws, especially insult laws that prohibit expressions directed against a state or its public

184 I believe that Article 311 of the Korean Criminal Act that criminalizes insult in general way should be abolished. As this paper restricts itself on the expressions against public officials, I argue that this provision, at least, should not be applied to public officials.

185 For analysis of the relationship between the two articles in Korean court practice, see Chung et al., supra note 155, at 79-80.

186 Lee posits that applying Article 311 to insulting expressions against public officials circumvents stricter requirements in Article 136 of the Korean Criminal Act that specifically provides criminal punishment for a person who uses violence or intimidation against a public official engaged in the performance of their duties. Lee, supra note 113, at 425.

Pyo argues that Article 311 should be abolished eventually. Pyo, supra note 103, at 37-39.

187 One way for South Korean courts is to apply Article 310, which provides exception for public interest, to insult law cases. Kim argues that the public interest in insult law cases against public figures, especially against elected public officials, should preclude criminality considering the right to know of general public. Kim, supra note 168, at 69. 
officials, should be abolished. If they are not abolished in their entirety, the high courts should at least allow for the fullest understanding of freedom of expression by protecting the freedom to insult the state, state symbols, and public officials. The high courts should declare insult laws, and the application of insult laws, to be unconstitutional. It is the role of the courts to make the letter of the law more closely reflect the values of a democratic society in practice.

Insult laws currently exist in other countries besides Mexico and South Korea. Journalists face imprisonment for insulting government officials and state institutions in more than 100 countries. ${ }^{188}$ In a 2017 study examining defamation and insult laws in the 57 participating States of the Organization for Security and Co-operation in Europe (OSCE), 36 OSCE states were found to have criminal laws prohibiting insult and/or desecration of state symbols, ${ }^{189} 9$ OSCE states have criminal laws that provide harsher criminal punishment for defamation or insult against a public official than against a private person, ${ }^{190}$ and 19 OSCE states have criminal laws prohibiting insult of the state. ${ }^{191}$ A report published in 2012 notes some progress in abolishing insult laws and criminal defamation in Africa, acknowledging, however, that there is much more room for improvement. ${ }^{192}$ In Latin America, desacato laws have been repeatedly identified as violating freedom of expressions in regional human rights law. ${ }^{193}$ In Asia, the Middle East, and Northern Africa, restrictions are routinely imposed on bloggers, journalists, and television stations for critical expressions. ${ }^{194}$ Additionally, the countries in the Southern African Development Community also continue to use insult laws against critics of public officials. ${ }^{195}$

While the cultural context of insult laws may vary from country to country, the basic value of freedom of expression in democratic societies is commonly shared. The challenges and successes of the various legal arguments raised in insult law cases give guidance to scholars, lawyers, and activists in their efforts to promote the free circulation of critical expressions and overcome the abusive use of insult laws in many countries. Insult laws should not be used as a means to silence critical expressions in any place in the world.

188 Ruth WALden, supra note 125, at 7. Winfield and Mendoza posit that the penalties against a journalist for insult are very severe including imprisonment and banishment from journalism. Winfield \& Mendoza, supra note 33, at 7.

189 Griffen, supra note 60, at 20-21.

190 Griffen, supra note 60, at 13.

191 Griffen, supra note 60, at 19-20; Yanchukova, supra note 3.

192 Raymond Louw, Introduction Furthering a Family Affair, in McCracken, supra note 4, at 2.

193 See the reports from the Inter-American System of Human Rights in I.(2) of this article.

194 McCracken, supra note 4, at 108, 142.

195 Balule, supra note 4. 